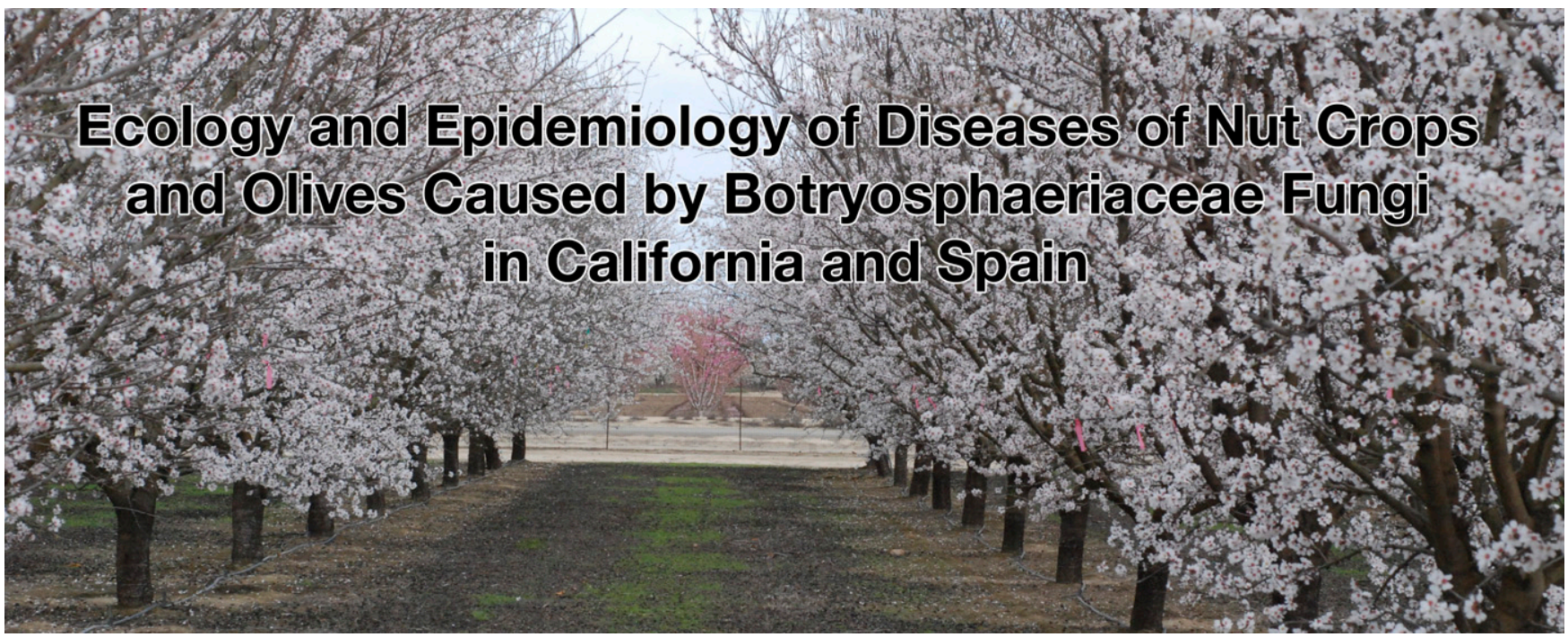

\author{
Juan Moral, ${ }^{1,2, \dagger}$ David Morgan, ${ }^{1}$ Antonio Trapero, ${ }^{2}$ and Themis J. Michailides ${ }^{1, \dagger}$ \\ ${ }^{1}$ Department of Plant Pathology, University of California, Davis, Kearney Agricultural Research and Extension Center, Parlier, \\ CA 93648, U.S.A. \\ ${ }^{2}$ Departamento de Agronomía, ETSIAM, Universidad de Córdoba, Campus de Rabanales, Edif. C4, 14071 Córdoba, Spain
}

Nut fruits, including almond, pistachio, and walnut, as well as olive oil, are essential foods of a healthy Mediterranean diet (Estruch et al. 2013). Beneficial effects of consuming nuts and olives include reduction of metabolic syndrome and a lower risk for cardiovascular disease and type 2 diabetes (Kris-Etherton et al. 2008).

Consumers' heightened interest in nutritional aspects of food during recent decades has led to a substantial increase in the worldwide production of almond, pistachio, and walnut. Almond, pistachio, and walnut production worldwide rose from 2,731 to 3,571 metric tons from 2010-11 to 2015-16. During this period, California produced around $45 \%$ of pistachio, walnut, and almond crops (Fig. 1A-C); it remains the world leader in almond production. Currently, Spain is ranked as the third almond producer worldwide with 53 metric tons after the U.S.A. and Australia but is ranked first in almond-growing area with 540,000 ha (www.magrama.gob.es). This discrepancy between output and production area is due to fact that most Spanish almond orchards have poor soils, depend on rain for irrigation, and consist of traditional, early-flowering, relatively low-yielding cultivars (Fig. 1D). Because almond orchards are more profitable than olive orchards, almond production is increasing, while olive production is stable in traditional olive-growing regions of Spain (D. Barranco, personal communication). The economic and social importance of olive is enormous in Spain, ${ }^{\dagger}$ Corresponding authors: T. J. Michailides, tjmichailides@ucanr.edu; and
J. Moral, juanmoralmoral@yahoo.es

Funding: We thank the California Pistachio Research Board (formally California Pistachio Commission), the Almond Board of California, and the California Walnut Board for the financial support of these studies. In addition, the following companies have contributed funding: Bayer, BiosSciences, BASF, DuPont, FMC, Luxemburg, Marrone, Nichino, Syngenta, Valent, Westbride, and others. Olive projects were funded by the Spanish Ministry of Education and Science and by the Andalusia Regional Government. Juan Moral holds a Marie Skłodowska Curie fellowship launched by the European Union's H2020 (contract number 658579).

The author(s) declare no conflict of interest.

Accepted for publication 1 April 2019.

(C) 2019 The American Phytopathological Society and it is the worldwide leader with more than 2.5 million ha (Fig. $1 \mathrm{E}-\mathrm{F}$ ) and economic value of $\$ 2.4$ billion (www.magrama.gob.es).

Cankers caused by species in the fungal family Botryosphaeriaceae are a major constraint to production of almond, pistachio, walnut (these three crops are collectively referred to as nut crops in this article), and olive. In general, these pathogens infect lignified tissues and, less frequently, fruit, leaves, and flowers (Teviotdale et al. 2002; Trapero et al. 2011). Reviewing the output of Botryosphaeria articles in APS journals, we noted that disease etiology, epidemiology/ecology, and control/resistance were addressed relatively equally until 2004, after which articles about etiology increased more than the other two types (Fig. 2). In this article, we review the current situation of the ecology and epidemiology of Botryosphaeriaceae species affecting almond, pistachio, olive, and walnut crops under Mediterranean conditions.

\section{Taxonomy and Description of the Diseases}

Botryosphaeriaceae family. Botryosphaeriaceae is a large family of filamentous fungi in the Ascomycota whose first members were described in the $1820 \mathrm{~s}$ as species of Sphaeria (Fries) (Phillips et al. 2013; Slippers et al. 2013). Cesati and De Notaris (1863) established the genus Botryosphaeria including 12 species in the second half of the 19th century. Theissen and Sydow (1918) introduced the Botryosphaeriaceae as a subfamily in the Pseudosphaeriaceae family. Major taxonomic diversification within the family during the first half of the 20th century was reviewed by Von Arx and Müller (1954). Currently, Botryosphaeriaceae encompasses 17 genera, of which Botryosphaeria, Diplodia, Dothiorella, Lasiodiplodia, Neofusicoccum, Neoscytalidium, and Macrophomina have been described as pathogens on nut crops or olive (Chen et al. 2014a; Gramaje et al. 2012; Inderbitzin et al. 2010; Phillips et al. 2013; Úrbez-Torres et al. 2013). Botryosphaeriaceae species show uni- to multilocular ascomata, occurring singly or in clusters; asci are bitunicate and clavate; ascospores can be hyaline or colored, and aseptate or 1 to 2 septate. Conidia can be hyaline and narrow or wide (called fusicoccum-like or diplodia-like, respectively), but colored conidia can be found in some species. Species in Neoscytalidium also produce arthrospores in chains as mature mycelia break into pieces (Phillips et al. 2013; Slippers et al. 2013). Morphological characteristics of conidia and colonies have been traditionally used for identifying Botryosphaeriaceae species affecting woody crops (English 1975; Michailides 1991; Romero et al. 2005). More recently, however, the morphologically based concept of species was displaced by the phylogenetic concept 
of species, which incorporates DNA sequence homology and phylogenetic analysis and has uncovered multiple cryptic species that originally belonged to a single morphological species (Taylor et al. 2000).

The phylogenetic approach has provided significant taxonomic changes during the last decade. The genus Botryosphaeria now includes $B$. agaves, $B$. corticis, $B$. dothidea, $B$. fabicerciana, B. fusispora, B. ramose, and B. scharifii (Phillips et al. 2013; Slippers et al. 2013). Interestingly, $B$. dothidea, which was considered the only species associated with panicle and shoot blight of pistachio for 10 years (Michailides 1991; Smith et al. 2001), is now considered a secondary pathogen in this host, whereas Neof. mediterraneum seems to be the main pathogen (Chen et al. 2014b; Moral et al. 2010). In general, Botryosphaeria species affecting nut crops and olives are nonobligate parasites that have a worldwide distribution. They can attack more than 150 species including angiosperms (both monocotyledonous and dicotyledonous) and gymnosperms. From an ecological point of view, Botryosphaeriaceae species have long been known as pathogens, saprophytes, and endophytes (Slippers and Wingfield 2007).
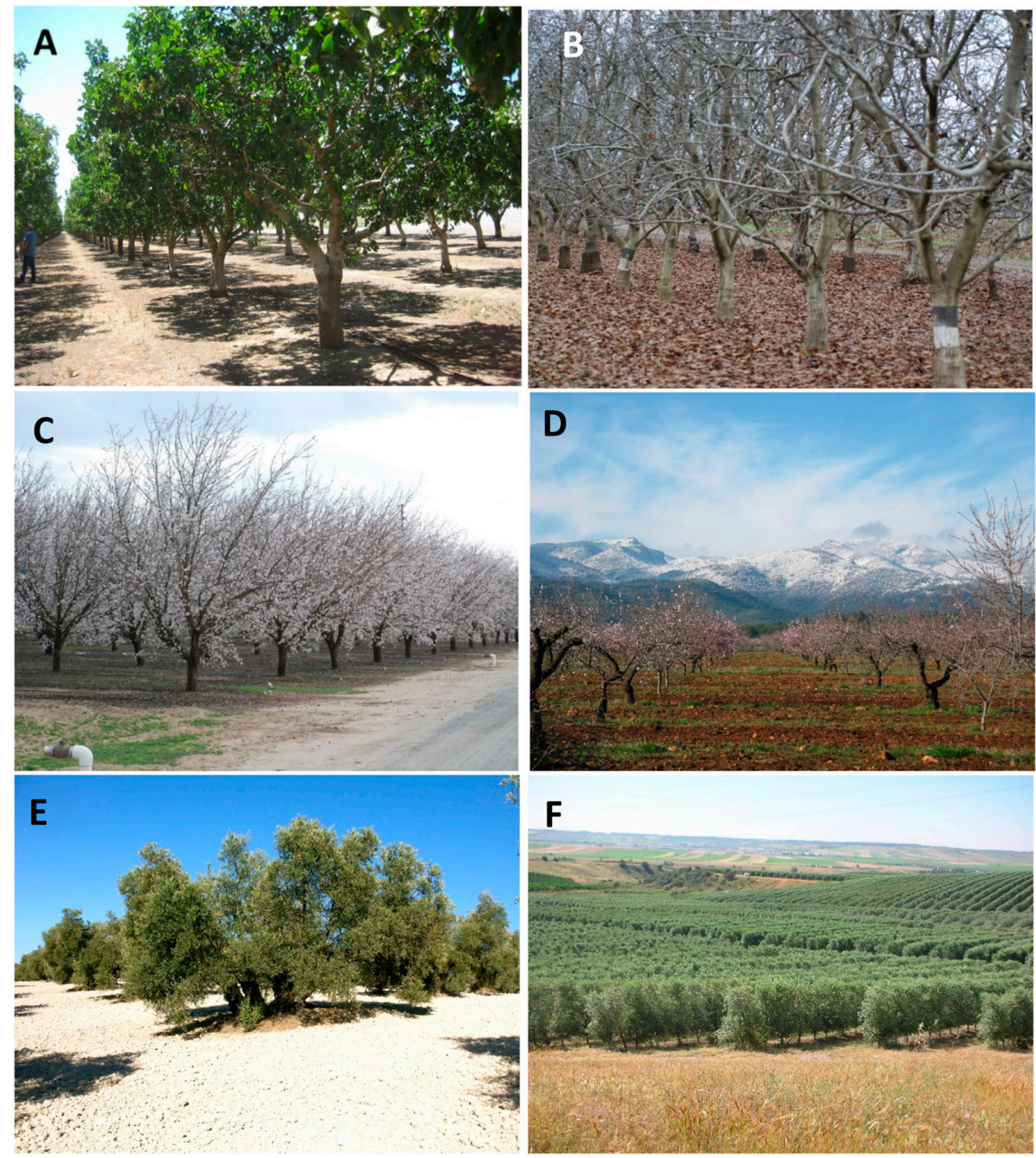

Fig. 1. Intensive pistachio (cv. Kerman) (A), walnut (cv. Howard) (B), and almond (cv. Nonpareil) (C) plantations in California. Traditional almond cv. Marcona plantation under rainfall conditions in southern Spain (D). Traditional multitrunk olive cv. Hojiblanca tree in southern Spain (E). Spanish super high density (hedgerow) olive cv. Arbequina plantation in southern Spain (F). 
Symptomatology, Economic Importance, and Etiology

Almond. A canker disease of almond trunk and scaffold branches caused by $B$. dothidea was described in California in the mid-1950s (English 1975). The pathogen kills the bark of almonds, causing a canker that expands horizontally in the tree trunk, forming a band that appears recessed (English 1975; Inderbitzin et al. 2010; Fig. 3A-B),

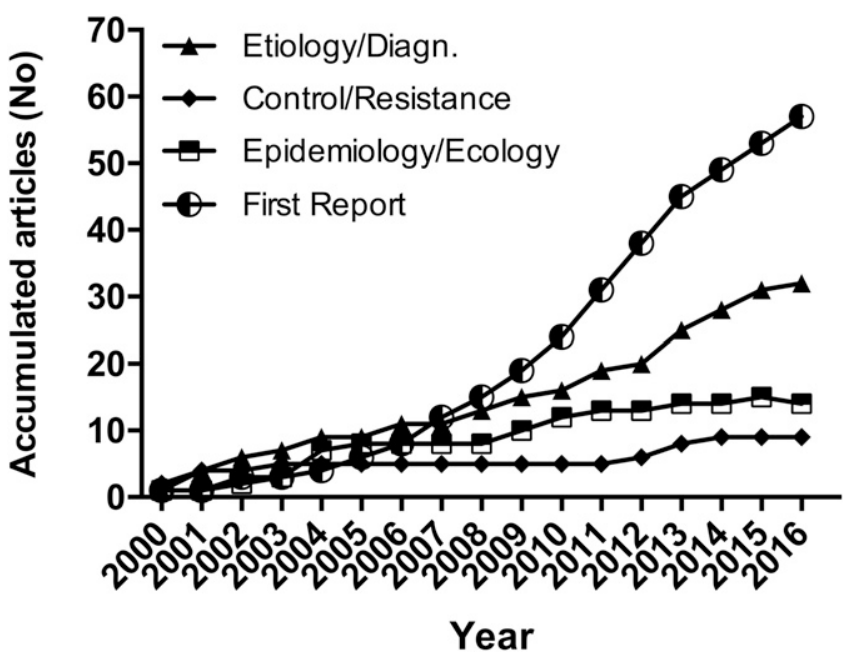

Fig. 2. Articles on Botryosphaeriaceae species published in American Phytopathological Society journals from 2000 to 2016, according to the topics of etiology, epidemiology/ecology, and control/resistance. resulting in the common name "band canker." Infection occurs through natural growth cracks in the bark caused by trunk growth. For this reason, symptoms often appear in 3- to 5-year-old trees on vigorous hybrid rootstocks. The pathogen, initially identified as $B$. dothidea, was reported to cause cankers of branches, shoots, and twigs of almond-so-called "canopy cankers"-in the 1980s. During the next decade, we also found cankers with exuding sap, a characteristic sign of cankers on this crop, around pruning wounds on almond branches (Michailides et al. 2018). Infections of trunk or scaffold branches can lead to initial wilting, thin canopy, chlorotic foliage, and gradual decline. Infection by Botryosphaeriaceae species can often cause the loss of the tree when the canker encircles the trunk. Moreover, severely affected trees are subject to breakage due to wind or harvesting. More rarely, cankers are formed in areas of the branches that bear nuts causing the blight of fruit with or without gumming (Fig. 3C-D).

In California, almond band canker was sporadic until the first years of the present century, when numerous severe outbreaks were reported (Michailides et al. 2009, 2018). In Merced County, four orchards showed $15.8 \%$ of almonds with typical disease symptoms (Doll et al. 2013). In Mallorca Island, Spain, prevalence of Botryosphaeriaceae pathogens in almond orchards is around $40 \%$ but associated with branch dieback rather than the band canker symptom (Olmo 2015). California almond nurseries have also experienced significant economic losses due to cankers caused by Botryosphaeriaceae species (Chen et al. 2013a). In many cases, when the plant is infected in the nursery, the cankers develop during the first years after plantation. Phylogenetic studies have revealed 11 Botryosphaeriaceae species (B. dothidea, D. olivarum, Dothiorella iberica, Neofusicoccum australe, Neof. parvum, Neof. mediterraneum, Neof. nonquaesitum, Lasiodiplodia theobromae, Diplodia seriata, Dot.
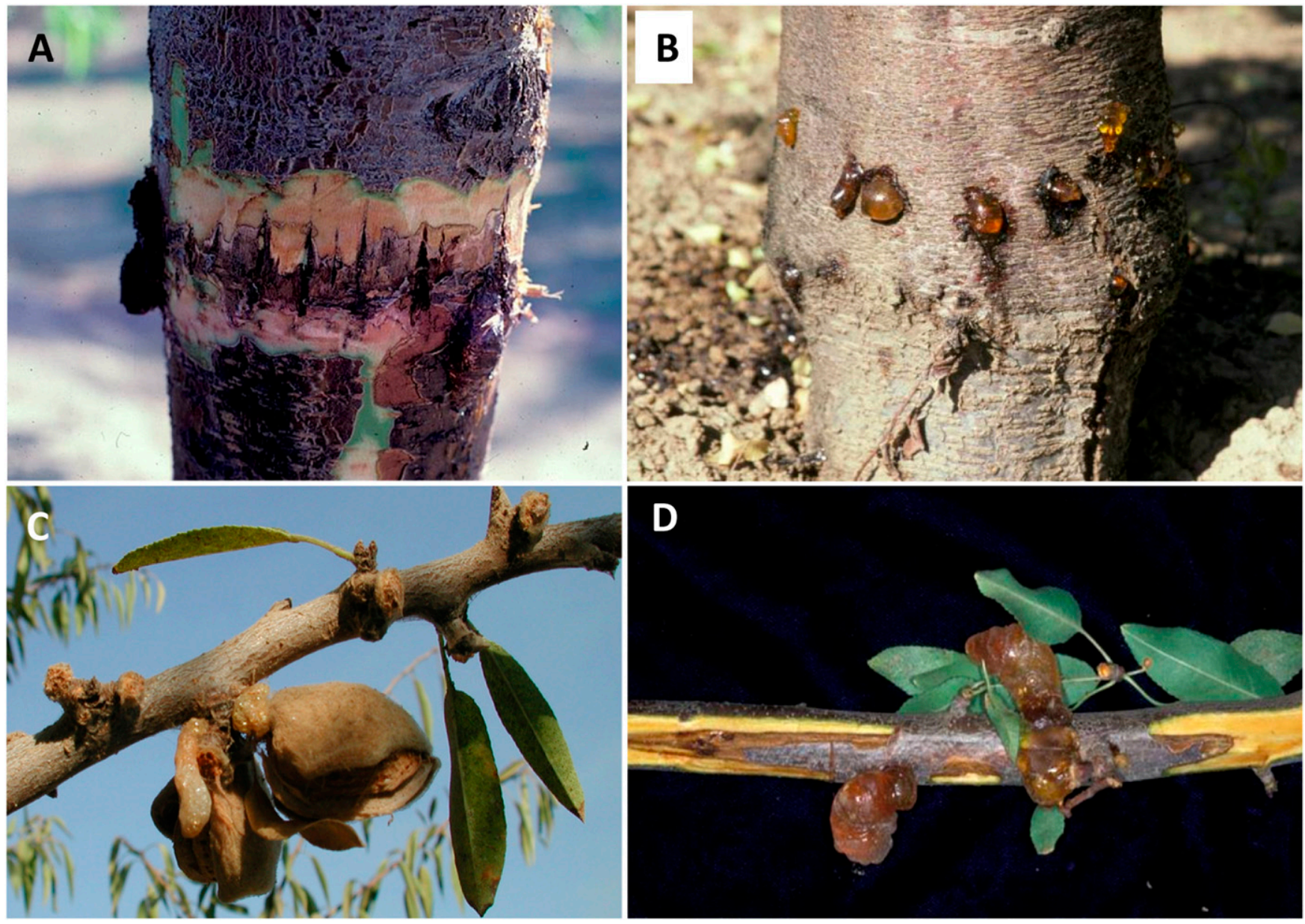

Fig. 3. Symptoms of Botryosphaeriaceae species affecting almond cv. Nonpareil: growth crack through which the pathogen infected the wood (A) and typical trunk gumming (B); blighted fruit (C) leading to canker formation (D). 
sarmentorum, and Macrophomina phaseolina) associated with band and canopy cankers in California and Spain (Chen et al. 2013a; Doll et al. 2015; Gramaje et al. 2012; Inderbitzin et al. 2010; Table 1).

Lower limb dieback (LLDB) is a complex syndrome known by farmers and farm advisors for the past 20 years. To date, this syndrome has been described in California, but similar symptoms to a lesser degree have been observed in Australian almond orchards (Michailides et al. $2009,2018)$. The affected almonds initially showed yellow leaves in the lower canopy, dieback of thin branches, and subsequently tufts of brown, blighted leaves. Although excess moisture in the soil during spring seems to play a major role in this problem (Lampinen et al. 2009), Botryosphaeria and Phomopsis (anamorph of Diaporthe) species have sometimes been isolated from symptomatic and asymptomatic branches of almond trees. In recent inoculation experiments, neither Botryosphaeria nor Phomopsis species caused symptoms on branches that resembled the LLDB symptoms. This fact, along with the absence of any effect of fungicide applications, suggest that both species may be secondary colonizers of almond limbs (Michailides et al. 2009).

Olive. Dalmatian disease of olive was first described in 1883 affecting fruit in the Dalmatia region of Croatia (Thümen 1883). In the Mediterranean Basin, the disease is known as "escudete" (translated as "small shield") in Spanish and Portuguese (Moral et al. 2010). Escudete develops in green fruit during the summer in sites associated with stings caused by the olive fly, Bactrocera oleae, which is the most important pest of this crop (Iannotta et al. 2007; Moral et al 2010). The characteristic symptom is a sunken, necrotic, circular lesion with a well-defined margin (Moral et al. 2010; Fig. 4A). During the winter, when the fruit is ripe, infected fruit will drop to the ground and become mummified, yet the initial symptom (shield) remains visible (Latinović et al. 2013; Moral et al. 2010; Fig. 4B). Escudete is widespread around the Mediterranean Basin including France, Italy, Montenegro, Portugal, Spain, and Tunisia (Chattaoui et al. 2011; Iannotta et al. 2007; Latinović et al. 2013; Margier 2014; Moral et al. 2010; Phillips et al. 2005; Zachos and Tzavella-Klonari 1979). The incidence of table fruit showing the typical necrotic shield frequently exceeds the tolerance level for the 'Extra' Class fruit, which is usually $2 \%$ or $4 \%$ (Moral et al. 2017a). The causal agent, which was originally identified as Phyllosticta dalmatica, underwent several taxonomic changes during the first half of the 20th century. In 1979, Zachos and Tzavella-Klonari (1979) classified the Dalmatian isolates within the genus Camarosporium as C. dalmaticum. However, Phillips et al. (2005) reclassified the pathogen as $B$. dothidea through DNA sequencing. Additionally, because ripe fruit have reduced resistance to fungal rot, a plethora of fungi, including several Botryosphaeriaceae species, can cause rot of black fruit (Moral et al. 2008). In this case, the symptoms usually appear as brown or black decay that covers part or all the fruit, with pycnidia formed on the fruit surface (Lazzizera et al. 2008a; 2008b; Sergeeva et al. 2009; Table 1).

Table 1. Virulence of Botryosphaeriaceae species affecting almond, pistachio, walnut, and olive

\begin{tabular}{|c|c|c|c|c|c|c|}
\hline \multirow[b]{3}{*}{ Pathogen species } & \multicolumn{5}{|c|}{ Host and virulence } & \multirow[b]{3}{*}{ References } \\
\hline & \multirow[b]{2}{*}{ Almond } & \multirow[b]{2}{*}{ Pistachio } & \multirow[b]{2}{*}{ Walnut } & \multicolumn{2}{|c|}{ Olive } & \\
\hline & & & & Branch & Fruit & \\
\hline Botryosphaeria dothidea & $\mathrm{MV}^{\mathrm{a}}$ & MV & MV & WV & WV & $\begin{array}{l}\text { Abdollahzadeh et al. 2013; Chen et al. 2014a, 2014b; Gramaje et al. } \\
\text { 2012; Inderbitzin et al. 2010; Lazzizera et al. 2008a, 2008b; } \\
\text { Mohammadi et al. 2015; Moral et al. 2010; Phillips et al. 2005; } \\
\text { Úrbez-Torres et al. 2013; }\end{array}$ \\
\hline Diplodia corticola & - & - & - & WV & - & Romero et al. 2005. \\
\hline D. mutila & $-\mathrm{b}$ & - & WV & MV & + & Chen et al. 2014b; Lazzizera et al. 2008b; Úrbez-Torres et al. 2013 \\
\hline D. olivarum & WV & - & - & - & + & Gramaje et al. 2012; Lazzizera et al. 2008b; Olmo 2015 \\
\hline D. pinea & - & - & - & - & + & Lazzizera et al. $2008 \mathrm{~b}$ \\
\hline D. scrobiculata & - & - & - & - & + & Lazzizera et al. 2008b \\
\hline D. seriata & WV & WV & WV & WV & WV & $\begin{array}{l}\text { Gramaje et al. 2012; Inderbitzin et al. 2010; Moral et al. 2008, 2010; } \\
\text { Olmo 2015; Úrbez-Torres et al. } 2013\end{array}$ \\
\hline Dothiorella iberica & + & WV & WV & WV & - & Chen et al. 2014b; Doll et al. 2015; Úrbez-Torres et al. 2013 \\
\hline Do. sarmentorum & WV & WV & - & - & - & Inderbitzin et al. 2010 \\
\hline Do. viticola & - & + & - & - & - & Mohammadi et al. 2015 \\
\hline Lasiodiplodia americana & - & MV & - & - & - & Chen et al. 2015 \\
\hline L. citricola & - & $\mathrm{HV}$ & $\mathrm{HV}^{\mathrm{c}}$ & - & - & Chen et al. $2014 \mathrm{~b}$ \\
\hline L. gilanensis & - & $\mathrm{HV}$ & - & - & - & Inderbitzin et al. 2010; Chen et al. 2014b \\
\hline L. theobromae & MV & MV & + & WV & & $\begin{array}{l}\text { Chen et al. 2013a, 2013b; Haggag et al. 2007; Úrbez-Torres et al. } \\
2013\end{array}$ \\
\hline Macrophomina phaseolina & MV & + & - & $t^{\mathrm{d}}$ & - & $\begin{array}{l}\text { Chen et al. 2014a; Gramaje et al. 2012; Inderbitzin et al. 2010; } \\
\text { Sergeeva et al. } 2005\end{array}$ \\
\hline Neofusicoccum australe & + & + & - & - & MV & $\begin{array}{l}\text { Armengol et al. 2008; Gramaje et al. 2012; Inderbitzin et al. 2010; } \\
\text { Lazzizera et al. 2008a }\end{array}$ \\
\hline Neof. hellenicum & - & MV & - & - & - & Chen et al. 2015 \\
\hline Neof. luteum & HV & - & MV & WV & + & $\begin{array}{l}\text { Martos 2008; Olmo 2015; Sergeeva et al. 2009; Úrbez-Torres et al. } \\
2013\end{array}$ \\
\hline Neof. mediterraneum & MV & MV & MV & $\mathrm{HV}$ & $\mathrm{HV}$ & Chen et al. 2014b; Moral et al. 2010, 2016; Úrbez-Torres et al. 2013 \\
\hline Neof. nonquaesitum & $\mathrm{HV}$ & - & MV & - & - & Inderbitzin et al. 2010; Chen et al. 2014a, 2014b \\
\hline Neof. parvum & $\mathrm{HV}$ & $\mathrm{HV}$ & $\mathrm{HV}$ & MV & WV & $\begin{array}{l}\text { Abdollahzadeh et al. 2013; Carlucci et al. 2013; Chen et al. 2014b; } \\
\text { Gramaje et al. 2012; Inderbitzin et al. 2010; Lazzizera et al. 2008a; } \\
\text { Martos 2008; Mohammadi et al. } 2015\end{array}$ \\
\hline Neof. vitifusiforme & + & MV & WV & WV & MV & $\begin{array}{l}\text { Chen et al. 2014a, 2014b; Inderbitzin et al. 2010; Lazzizera et al. } \\
\text { 2008a; Úrbez-Torres et al. } 2013\end{array}$ \\
\hline Neoscytalidium dimidiatum & + & + & $M V^{c}$ & - & - & Chen et al. 2014b \\
\hline
\end{tabular}

${ }^{\mathrm{a}} \mathrm{HV}, \mathrm{MV}$, and $\mathrm{WV}=$ highly, moderately, and weakly virulent, respectively.

${ }^{\mathrm{b}}$ Species nondescribed $=-$; Species described but nonvirulence test data to compare $=+$.

${ }^{\mathrm{c}}$ Species causing infection in graft union of walnut trees in commercial nurseries (Chen et al. 2014a).

${ }^{\mathrm{d}}$ Species associated to root rot in young olive trees (Sánchez-Hernández et al. 1998; Sergeeva et al. 2005) and young almond trees in California. 
In 2005, Romero et al. (2005) described branch dieback caused by Botryosphaeriaceae species on olive cv. Gordal Sevillana in southern Spain. The pathogen usually affects thin shoots $(<20 \mathrm{~mm}$ in diameter) that can show sunken cankers or open wounds (Moral et al. 2010, 2017a). Overall, blighted shoots appear to be homogeneously distributed in the olive canopy (Fig. 4C). The extent of yield losses caused by this disease are uncertain. The pathogen kills productive shoots (and thereby cuts yield), but even if the infection does not cause the death of the affected branch, it reduces the normal growth of trees (Moral et al. 2010, 2017a). In severely affected orchards, between 70 and $90 \%$ of mature olives cv. Gordal Sevillana show branch dieback, even under good management practices. In these orchards, the pathogen destroys up to $14 \%$ of the total canopy of the orchard, with individual trees showing $>25 \%$ canopy volume loss. The pathogen was originally identified as $B$. ribis but was subsequently reclassified as Neof. mediterraneum (Moral et al. 2010). Nine Botryosphaeriaceae species have now been identified as causal agents of olive branch dieback in California, Italy, and Tunisia (Carlucci et al. 2013; Chattaoui et al. 2012; Kaliterna et al. 2013; Moral et al. 2010, 2017a; ÚrbezTorres et al. 2013; Table 1).

Pistachio. Panicle (i.e., a branched inflorescence) and shoot blight is the most important pistachio disease. The pathogen was reported as a new species of Camarosporium (C. pistaciae) in Greece in 1974 (Zachos et al. 1974), and 10 years later as $B$. dothidea in California (Rice et al. 1985). The pathogen causes cankers that can reach up to $30 \mathrm{~cm}$ in length, covered with dark exudate when it occurs in the trunk or scaffold branches (Michailides and Morgan 2004). The fungus can invade the xylem and sometimes cause V-shaped cankers in cross section. The disease does not usually kill branches or entire trees; instead, pistachios can heal around cankers to prevent further expansion. Botryosphaeria panicle and shoot blight also causes major damage to current growth, including shoots, panicles, and leaves (Ntahimpera et al. 2002; Fig. 5A). Shoot infection can also occur at postharvest through bud, leaf, and panicle scars (Ahimera et al. 2003; Michailides and Morgan 1992; Moral et al. 2017b). Shoots originating from heavily infected or partially killed buds expand briefly, then turn black and frequently collapse. The killing of male buds may not impact yield because male pistachio trees produce abundant pollen (Michailides and Morgan 2004). However, infection of flower buds of female trees can lead to infection of panicles at the rachis base; panicle collapse is the most devastating phase of the disease (Moral et al. 2017b). Furthermore, the pathogen can infect the base of the petiole or the base of the leaflet of pistachio leaf, leading to leaf or leaflet blight and defoliation during the summer. Direct infection of leaves via stomata leads to necrotic black lesions in the spring, whereas in the summer lesions have brown centers with chlorotic margins and develop some pycnidia scattered on the central surface of the lesion. Leaf infections become irregular to round brown lesions ( $\leq 25 \mathrm{~mm}$ in diameter) with chlorotic margins (Michailides and Morgan 2004). In pistachio fruit, direct infection via lenticels by Botryosphaeriaceae pathogens appear as rounded, black, pin-head-sized (1 to $3 \mathrm{~mm}$ in diameter) lesions, but these lesions can cover extensive areas and even the entire fruit (Fig. 5B). The epicarp may be covered with a layer of pycnidia with an appearance like black pepper granules on the epicarp surface (Michailides and Morgan 2004).

The pathogen causes extensive losses in pistachio-growing areas during epidemic years. During the late 1980s, yield losses from 40 to $100 \%$ were common in the northern counties of California (Michailides 1991; Michailides and Morgan 2004). In 1998, after a warm and extraordinarily wet "El Niño" event, disease impact was very severe due to a combination of favorable weather and ineffective fungicides. In the words of the Californian growers, it was a "Bot year;" total production lost to the disease was estimated at 9 million $\mathrm{kg}$ (Michailides and Morgan 2004). Pistachio production history in California shows several consecutive years of severe epidemics due to panicle and shoot blight; for example, such a series began after a very wet spring in 1995 and broke the upward linear trend of production during the "On years" (Fig. 6). In nurseries, Botryosphaeriaceae species also cause significant economic losses since the pathogens cause stem cankers near the graft union that can result in the death of young trees (Chen et al. 2014a; Swart and Botes 1995). Pistachio panicle and shoot blight has been described in most countries growing pistachios, including Australia, Italy, Iran, Spain, and South Africa (Armengol et al. 2008; Mohammadi et al. 2015; Slippers et al. 2007; Wunderlich et al. 2012). The number of Botryosphaeriaceae species recorded in pistachio has increased to 15 , including B. dothidea, D. seriata, Dot. iberica, Dot. sarmentorum, Dot. viticola, L. americana, L. citricola, L. gilanensis, L. theobromae, M. phaseolina, Neof. australe, Neof. mediterraneum, Neof. hellenicum, Neof. parvum, and Neof. vitifusiforme (Armengol et al. 2008; Chen et al. 2014a, 2014b, 2015; Inderbitzin et al. 2010; Table 1).
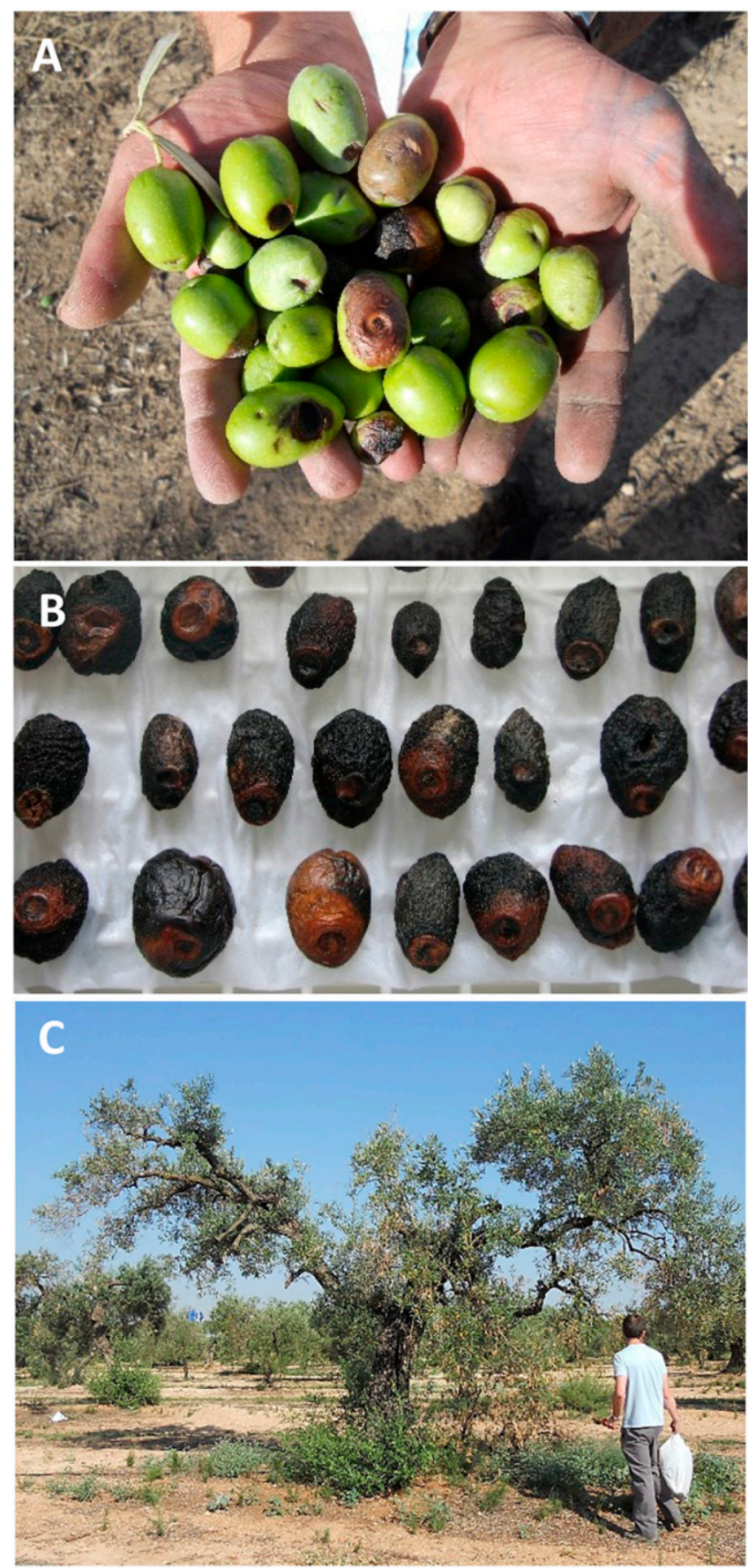

Fig. 4. Symptoms of Botryosphaeriaceae species affecting olive cv. Gordal Sevillana Typical "escudete" (= "small shield") caused by Botryosphaeria dothidea in olive fruit (A). Mummified fruit infected by $B$. dothidea showing the original "escudete" symptom (B). Olive tree showing dieback of branches caused by Neofusicoccum mediterraneum (C) 
Walnut. Botryosphaeria canker and blight of walnut was described by H. Fawcett as "melaxuma of the walnut" in 1915 in California, but farmers had noticed the disease since 1909 (Fawcett 1915). The main symptoms are cankers on the trunk of young trees and scaffold branches of mature trees (Fig. 5C). Dieback of spurs (short shoots that bear flower buds, and then flowers and fruit in the following year) results from infections moving from affected fruit via the peduncle or shoots through leaf and peduncle scars. Shoots and spurs infected by Botryosphaeriaceae fungi show bumpy areas that are not uniformly distributed. In contrast, shoots infected by Phomopsis species (also associated with the disease) produce pycnidia whose ostioles are uniformly distributed on the surface of the shoot. Moreover, for Botryosphaeriaceae species that have hyaline conidia, the contents of pycnidia appear glassy and transparent, whereas pycnidia of Phomopsis spp. appear cloudy and offwhite following superficial, longitudinal sectioning of the shoots. The husks of walnut fruit are highly susceptible to Botryosphaeriaceae infections; the pathogens cause latent infections in developing fruit and black-brownish lesions in mature ones. The lesions advance quickly, consuming the entire fruit and developing pycnidia (Fig. 5D). Lesions are usually restricted to the husk, but some species can colonize the kernel. Thus, Botryosphaeriaceae spp. and Phomopsis spp. can be detected in infested (or killed) walnut buds during winter (Michailides et al. 2014). Although economic losses are considerable, these are difficult to estimate-first, because it is tough to separate damage caused by Botryosphaeriaceae spp. from that caused
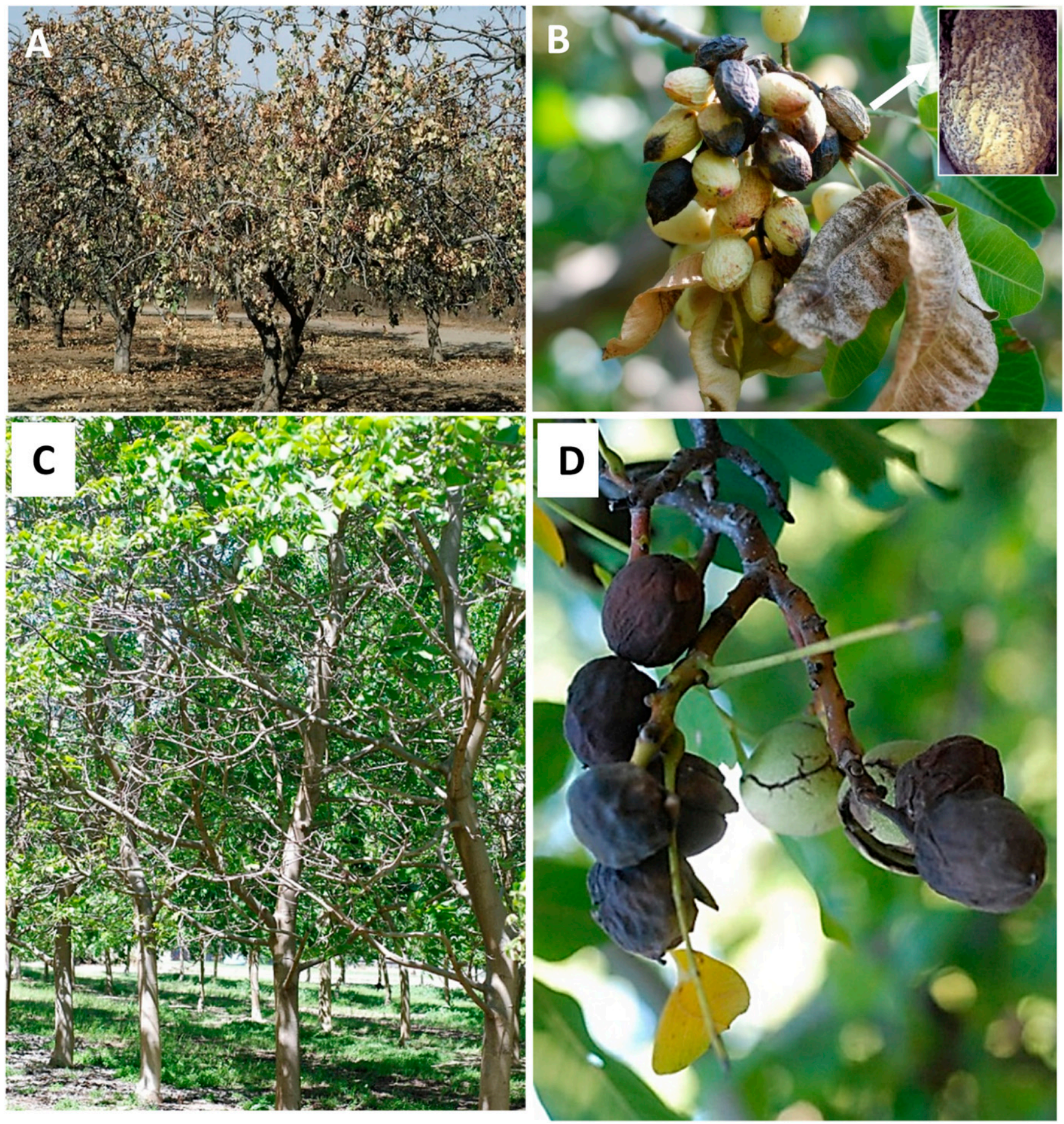

Fig. 5. Symptoms of Botryosphaeriaceae species affecting pistachio and walnut. Pistachio cv. Kerman showing general blight of canopy (A). Infected fruit of pistachio cv. Kerman by Neofusicoccum mediterraneum (B). Walnut orchard cv. Vina showing dieback of branches (C). Fruit walnut cv. Chandler infected by Botryosphaeriaceae species (D). 
by Phomopsis spp. (Michailides et al. 2014), and second, because Botryosphaeriaceae spp. are frequently associated with walnuts showing decline due to natural causes in well-maintained orchards or to pest injury, and whose etiology is difficult to determine. Also, significant economic losses occur in nurseries due to infection of the graft union, which is particularly susceptible to fungal infection in young walnuts (Chen et al. 2013b). Botryosphaeria canker and blight

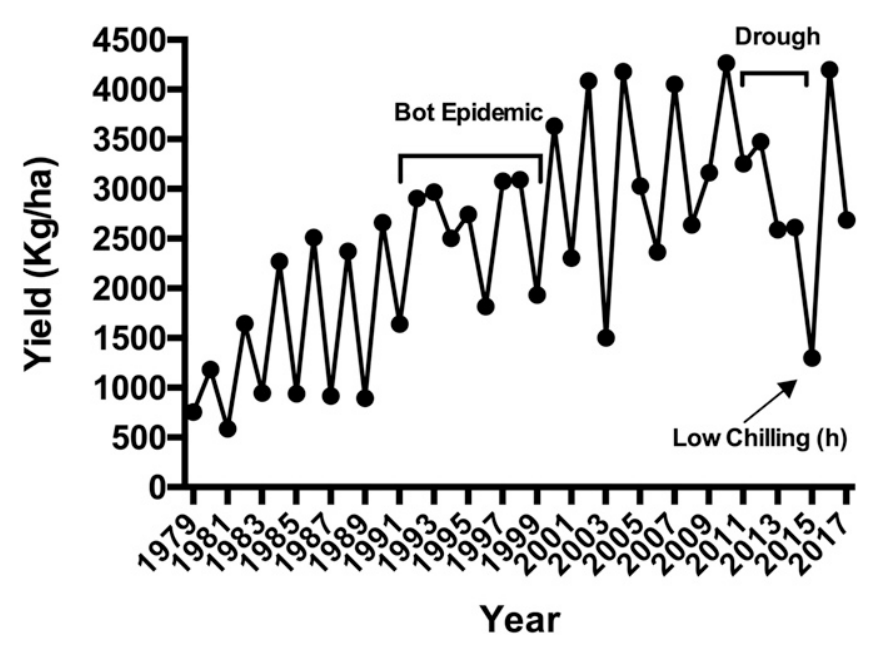

Fig. 6. Pistachio yields (kg/ha) in California from 1979 to 2017. Note the effects of the Botryosphaeria panicle and shoot blight epidemics (1995-1998), drought period (2012-2014), and low chilling hours during winter of 2014 of walnut has been reported in many different walnut-growing countries including China, Greece, Egypt, Iran, and Spain (Abdollahzadeh et al. 2013; Haggag et al. 2007; Moral et al. 2010; Rumbos 1987; Yu et al. 2015), as well as the U.S. Chen et al. (2014a) described the following 10 species-B. dothidea, D. mutila, D. seriata, Dot. iberica, L. citricola, Neof. mediterraneum, Neof. nonquaesitum, Neof. parvum, Neof. vitifusiforme, and $N$. dimidiatum-affecting walnut in California (Table 1).

\section{Rise of the Diseases}

In the last decade or so, we have observed a rise in the number and severity of diseases caused by Botryosphaeriaceae fungi that can be attributed to several causes.

Agricultural practices. In California and the Mediterranean Basin, nut crops and olive plantings are often established in humid areas such as near riverbanks that provide a favorable environment for infection and where wild hosts (blackberry, black walnut, cottonwood, deodar cedar, eucalyptus, willow, and others) of Botryosphaeriaceae spp. frequently thrive (Inderbitzin et al. 2010; Michailides et al. 2014; Moral et al. 2010; Fig. 7A-B). In the San Joaquin Valley of California, for example, almonds, grapes, pistachios, walnuts, and olives grow in contiguous areas, allowing a flow of inoculum among these hosts. Similarly, olive and other woody crops affected by Botrysosphaeriaceae spp. (e.g., almond and grapevine) usually grow in neighboring orchards in Mediterranean countries (Fig. 7C-D). Furthermore, rising land prices, shifting agronomic trends, and increasing profitability of almond, pistachio, olive, and walnut production have resulted in the redesign of orchards during the last 40 years. For example, plant density has increased to modern super high density systems called hedgerow systems. In hedgerow systems (Fig.
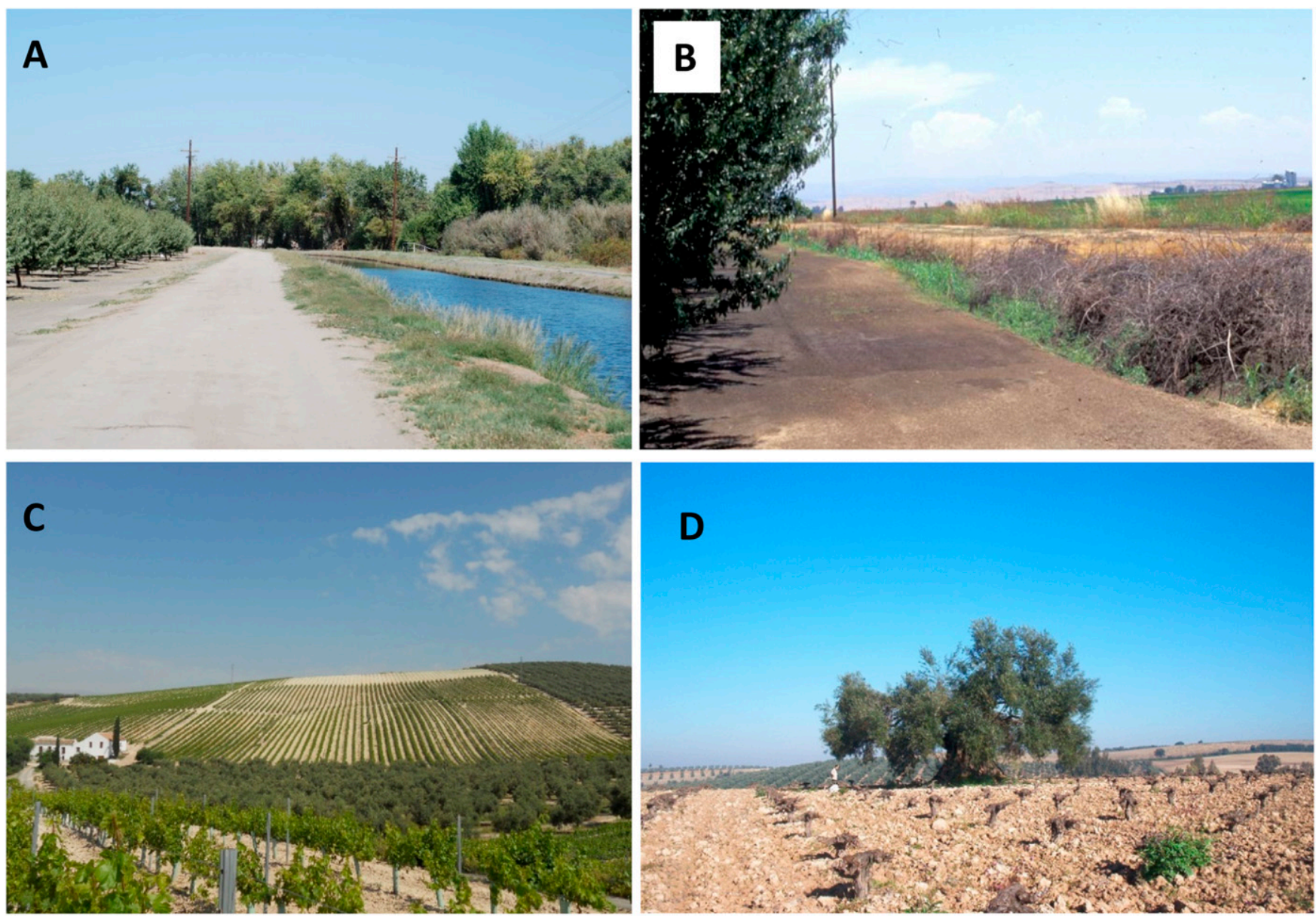

Fig. 7. Hosts of Botryosphaeriaceae species growing contiguously, which allows cross-inoculum among them. Californian pistachio orchards close to riparian areas that serve as inoculum sources for the pathogen (A and B). Typical landscape with Botryosphaeriaceae host crops (olives and grapevines) in southern Spain (C). Centenary olive tree growing in the center of a grape vineyard in southern Spain (D). 
$1 \mathrm{~F})$, the trees are closely planted in the row forming a continuous canopy where the productive unit is the linear meter of the row rather than the individual tree (Díez et al. 2016). Currently, hedgerow systems are common for walnut and olive production, and the first trials with almonds are being conducted. For many pathosystems, microclimatic changes resulting from higher plant densities can create conditions more conducive to disease development by increasing the duration of wetness on the tree canopy. For example, anthracnose epidemics, caused by Colletotrichum species, progress faster in hedgerow olive plantings than in high-density ones (Moral et al. 2012).

In California and Spain, olives in hedgerow systems are harvested using canopy-contact harvesters (grape harvesters), whereas almonds, pistachios, olives (in traditional plantations), and walnuts are usually harvested using mechanical trunk shakers that vibrate the trunk for a few seconds, resulting in fruit drop. Both trunk shakers and canopy-contact harvesters cause several types of injuries to the trees such as loss of portions of trunk bark or wounding and breaking of scaffold branches that facilitate infection by Botryosphaeriaceae species. Likewise, wounds caused by pruning tools facilitate infection by these and other fungal species such as Basidiomycetes (Michailides 1991; Úrbez-Torres et al. 2013; Fig. 8A-E). Both hand pruning and mechanical pruning methods are used on nut crops and olive trees with varying frequency and intensity, depending on the area where the crop is growing and the intensity of crop production. For instance, most California almond and Turkish pistachio orchards hold as their general principle, "the more you prune, the more you reduce yield," whereas in much of the Mediterranean Basin, traditional pistachio and olive orchards implement annual hand pruning. In any case, if conditions are conducive and inoculum is present, pruning wounds may become infected, and cankers may develop around the wounds (Agustí-Brisach et al. 2019; Michailides and Morgan 2004). Both harvesters and pruning tools can also move inoculum of pathogens within and between orchards. In summary, more intensive cropping systems are susceptible to a higher risk of infection by Botryosphaeriaceae species as a result of extended periods of wetness, decreased the sunlight penetration into tree canopies, more wounding of trees, and ultimately more inoculum sources (i.e., symptomatic trees) per orchard area, thereby increasing the opportunity for infection.

We have also observed exacerbation of almond band canker associated with the use of vigorous rootstocks (e.g., cv. Hansen) since these rootstocks cause more growth cracks in the trunks (i.e.,
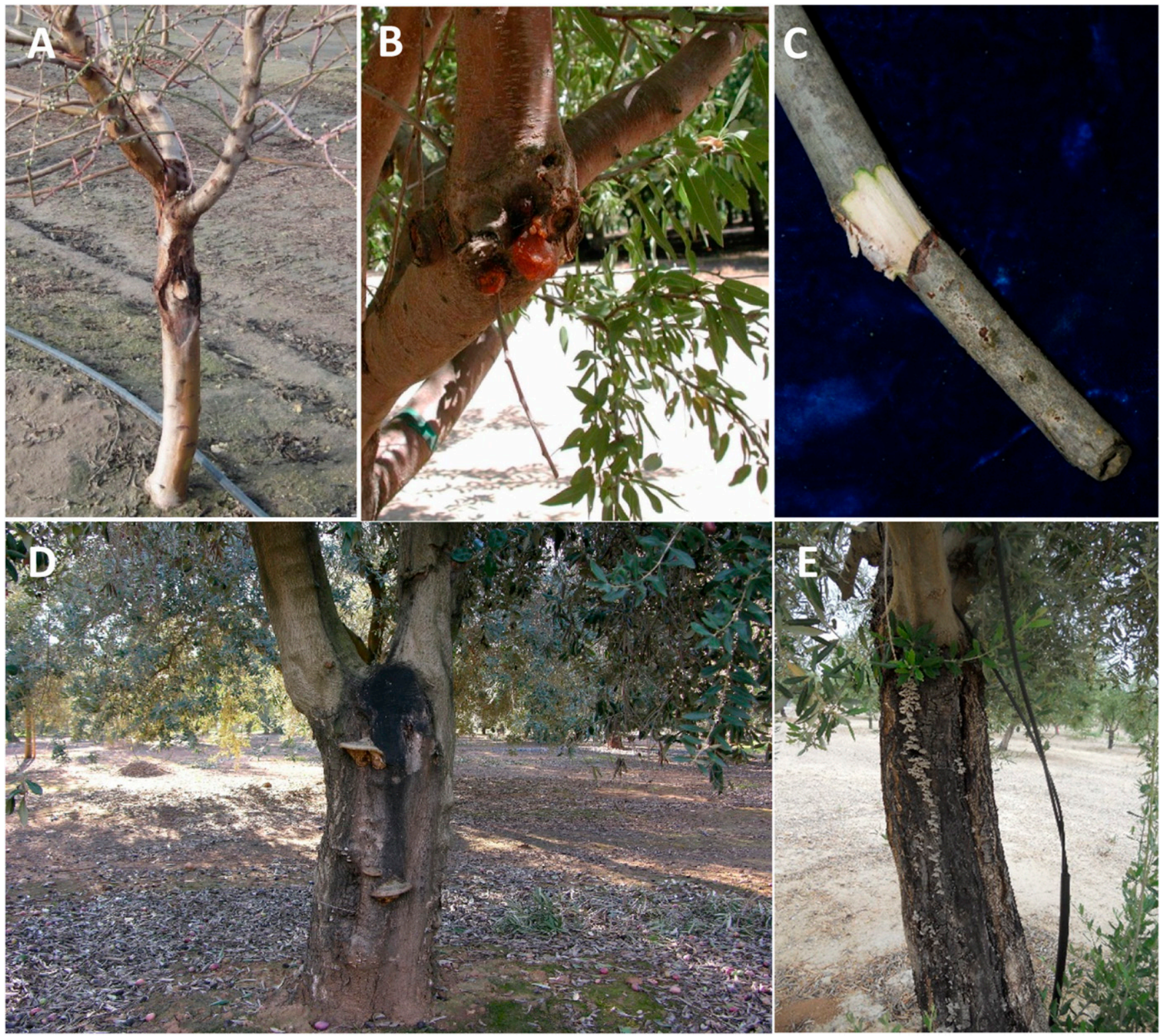

Fig. 8. Fungal infection associated with pruning and harvest wounds. Colonization of almond trunk and scaffold branch (exuding sap) through pruning wounds by Botryosphaeriaceae spp. (A and B). Colonization of walnut shoot through pruning wound by Neofusicoccum parvum (C). Basidiomycete species associated with scaffold pruning cut in an olive tree (D). Basidiomycete species associated with damages caused by a trunk shaker in an olive tree cv. Picual (E). 
entryways of infection) than the less vigorous rootstocks (Moral et al. 2019). Finally, increased regulatory restriction on the use of effective fungicides may have amplified damage caused by these pathogens. For example, following the removal of benomyl (particularly effective against Botryosphaeria species) for use in the European community, major outbreaks of Neof. mediterraneum affecting olives in southern Spain were reported (Moral et al. 2010; Romero et al. 2005). Over the years, outbreaks of some fungal diseases have been associated with resistance to certain fungicides, but this has not been clearly demonstrated for diseases caused by Botryosphaeriaceae species (Michailides and Morgan 2004).

Buildup of inoculum. Extreme weather conditions (El Niño and drought years) could have affected other fungi such as Phomopsis species or pests such as walnut scale (Quadraspidiotus juglansregiae) and stinkbugs (Hemiptera) attacking pistachio and almond, thus increasing the pressure of parasitic organisms in the tree and increasing vulnerability to outbreaks of Botryosphaeriaceaeincited diseases (Michailides et al. 2013, 2014; Michailides and Morgan 2016). For example, the susceptibility of walnut branches to different Botryosphaeriaceae species increased when scales were present in them (Moral et al. 2019). Large hemipteran insects (Leptoglossus clypealis, Chlorocoa, and Thyantha spp.) facilitate pathogen infection by not only spreading Botryosphaeriaceae pathogens but also creating wounds in host tissue (Michailides et al. 2014). In olives, the traditional burning of pruning residues reduces fungal inoculum. Currently, however, prunings are chipped and mulched onto the ground, which may increase inoculum in orchards. In walnut, however, composting debris generated in hullers, even when $90 \%$ of the hulls had pycnidia of Botryosphaeriaceae or Diaporthaceae fungi, resulted in no survival of these pathogens; it is therefore considered safe to return composted material back in the orchard (Michailides et al. 2014; Moral et al. 2019).

Weather conditions and climate change. Risk of an outbreak of Botryosphaeriaceae-incited diseases peaks in seasons with excessive rainfall due to infection occurring mainly from water-splashed conidia (Ahimera et al. 2004). Because pathogen infections during the fall and winter frequently remain latent until the next spring and summer, accumulation of latent infections and buildup of inoculum during periods with high rainfall also increases the risk of disease in subsequent years (Michailides and Morgan 2004). The occurrence of "El Niño" events at irregular intervals of 2 to 7 years can lead to cyclic epidemics where these diseases are not managed every year. Also, if a year with high rainfall is followed by a drought year, symptoms caused by Botryosphaeriaceae species are typically severe because periods of water stress increase host susceptibility (Marsberg et al. 2017; Piškur et al. 2011; Stanosz et al. 2001). For example, pistachios under water stress show greater susceptibility to Neof. mediterraneum than nonstressed trees (Ma et al. 2001). Trees severely damaged by low temperatures can also become more susceptible to pathogens due to increased cracking and wounding. In Croatia, Kaliterna et al. (2013) described an epidemic of $D$. seriata (usually a weak pathogen) associated with dieback of young olive trees that had been exposed to exceptionally low temperatures during the previous winter.

More frequent extreme weather is predicted by most climate change models, along with a significant increase of summer air temperature and water stress on many crops in the Mediterranean Basin (Lung et al. 2013). In California, in addition to an increase in temperature, recent predictions point to an increase in annual precipitation from 3.3 to $15.2 \%$ (Allen and Luptowitz 2017). Both increased plant stress (Mediterranean Basin) and precipitation (California) could increase the severity of Botryosphaeriaceaeincited diseases.

\section{One Pathogen on Multiple Hosts and One Host With Multiple Pathogens}

To date, no Botryosphaeriaceae species has been identified that is specific to particular nut or olive crops. Instead, almost all plantpathogenic species in this family occur on multiple species within these crop groups. However, Dot. viticola has been described only from pistachio among the crops in this review (Mohammadi et al. 2015), and D. pinea and D. scrobiculata cause olive fruit rot but have not been reported from almond, pistachio, or walnut (Lazzizera et al. 2008b). In contrast, B. dothidea, D. seriata, Neof. mediterraneum, and Neof. parvum can infect almonds, olives, pistachios, and walnuts (Chen et al. 2014a, 2014b; Gramaje et al. 2012; Inderbitzin et al. 2010; Lazzizera et al. 2008a, 2008b; Úrbez-Torres et al. 2013). Diplodia and Dothiorella species are weakly virulent in almond, pistachio, olive, and walnut crops, whereas L. citricola, Neof. mediterraneum, and Neof. nonquaesitum are considered at least moderately virulent (Chen et al. 2014a; Inderbitzin et al. 2010; Moral et al. 2010; Úrbez-Torres et al. 2013). Interestingly, $B$. dothidea is not considered to be a highly virulent pathogen in any of these crops (Table 1). Differences in virulence have also been observed among isolates belonging to the same species (Moral et al. 2017a).

In California and Spain, virulence of a given Botryosphaeriaceae species in a given host may not necessarily be correlated with its isolation frequency. The pathogen's fitness can also depend on other factors such as i) its virulence in nearby cultivated and wild hosts, ii) biology of its saprophytic phase, iii) adaptation to prevailing climate conditions, and iv) resistance to fungicides. For example, D. seriata, which is considered a weakly virulent pathogen in olive and nut crops (Inderbitzin et al. 2010; Moral et al. 2010; Table 2), was the most frequently isolated species from almond orchards showing tree decline in Mallorca, Spain (Olmo et al. 2016). In contrast, D. seriata is considered a minor species in California orchards, where the moderate virulent species Neof. mediterraneum is dominant in pistachio ( $86 \%$ of isolations), walnut (76\% of isolations), almond, and olive orchards (Chen et al. 2014a, 2014b; Inderbitzin et al. 2010; Moral et al. 2010). In the Andalusia region of Spain, after monitoring the fungal fruiting structures on blighted branches from several commercial olive orchards, it was determined that $26.3 \%$ of them were Neof. mediterraneum. (Moral et al. 2015, 2017a).

\section{Disease Cycle}

The disease cycles of Botryosphaeriaceae species in almond, pistachio, olive, and walnut crops are influenced by the perennial nature of these crops and by the climate. In general, Mediterranean climates are typified by at least two consecutive dry months during the summer and a cool or mild, wet winter. Asexual spores (pycnidiospores) are the main inoculum source, and sexual spores (ascospores) have a limited role in the disease cycle (Inderbitzin et al. 2010; Michailides and Morgan 2004; Moral et al. 2010, 2015; Fig. 9). Depending on the disease, epidemic risk can be strongly influenced by the presence of insects that may increase the plant's susceptibility or act as vectors (Table 2). Botryosphaeriaceae species have a saprophytic phase in which they colonize tree bark as well as plant tissues that have fallen to the soil surface (Michailides et al. 2018).

In contrast to the general disease cycle shown in Figure 9, M. phaseolina is primarily a root pathogen. It is well known as the causal agent of a decline of olive (Sánchez-Hernández et al. 1998; Sergeeva et al. 2005) and young almonds in commercial orchards (Michailides, unpublished data). Recently, we documented several hundred young olive trees (cv. Sikitita) affected by M. phaseolina in southern Spain, attributed to a high density of inoculum due to previous plantation of sunflower, and increased susceptibility due to irrigation with semisaline water (Moral, unpublished data).

\section{Pathogen Survival}

On crops. Botryosphaeriaceae species can overwinter and oversummer as pycnidia or pseudothecia, which develop within a stroma. Often, the stroma develops a wall that is only a few cells thick covering the fruiting bodies (Brooks and Ferrin 1994), whereas in other cases it exhibits a thick, strongly melanized tissue (Moral et al. 2007). In general, thicker stromata are more resistant to degradation. Epidermal layers of infected tissues can also protect the stroma and fruiting bodies from climatic factors and fungicides. Botryosphaeriaceae species can survive in cankered trunks, killed 
branches, blighted shoots and spurs, killed buds, and blighted fruit (English 1975; Michailides 1991). If the pathogen infects plant tissues that develop yearly (for example, fruit or leaves of deciduous trees), the pathogen survives the intervening period in infected tissues (cankered or not) on the tree canopy or the ground (Moral et al. $2010,2017 b)$. In the latter case, saprophytic microorganisms compete with the pathogen, decreasing its viability. Survival of the pathogen is markedly reduced if cankered branches are chipped. Michailides (1991) reported that infected rachises and fruit are retained on pistachios longer than healthy ones. In this host, viable pycnidiospores are recoverable from blighted rachises and cankers for 2 and 6 years, respectively (Michailides 1991). The presence of pycnidia or pseudothecia in the branches heavily depends on the host; thus, while fruiting bodies are easily found in cankered branches of pistachios, olives, and walnuts (Michailides and Morgan 2004; Moral et al. 2015, 2017a; Úrbez-Torres et al. 2013), they are rarely found in almond shoots or spurs. However, pseudothecia intermixed with abundant pycnidia have been found in the bark of almond trunks with severe band canker symptoms, in stumps of almonds killed by Botryosphaeriaceae species (Michailides et al. 2009), and in blighted shoots of walnuts found on the ground under the trees and attached on the tree. In the case of pistachio and walnut, Botryosphaeriaceae species can also overwinter in infected and blighted buds (Ntahimpera et al. 2002; Michailides and Morgan 2004; Michailides et al. 2014).

Alternative hosts and the environment. When healthy trees from a nursery are planted, spores arrive from neighboring trees within the same field or nearby alternative hosts, whereas within affected orchards internal sources of inoculum cause most new infections (Figs. 10 and 11). Except for M. phaseolina, which survives in soil for long periods as microsclerotia, most Botryosphaeriaceae species appear to survive poorly in the soil.

\section{Sources of Inoculum and Spore Dispersal}

Botryosphaeriaceae species can develop inoculum in all tree tissues. In Californian pistachios, pycnidia forming on blighted tissues are the main source of inoculum for panicle and shoot blight (Chen et al. 2014b; Michailides 1991; Michailides and Morgan 2004). However, pseudothecia are common in chaparral vegetation and other woody hosts in California (Inderbitzin et al. 2010; Michailides and Morgan 2004; Moral et al. 2010). In almonds with LLDB, pycnidia of Botryosphaeriaceae species did not develop in the affected limbs, which instead bore pycnidia of Phomopsis species (Michailides et al. 2009). Hence, it is questionable whether the dead shoots of almond can serve as sources of inoculum for Botryosphaeriaceae species. Instead, pycnidia of the pathogen intermingled with pseudothecia are frequent in the bark of cankered almond trunks and scaffold branches. Stumps of removed trees and other hosts in the proximity of almond orchards can also serve as sources of inoculum (English 1975). Inoculum sources of Botryosphaeriaceae diseases affecting walnuts and olives are less known, although in both hosts the cankered shoots, branches, spurs, and fruit (in the case of walnut) frequently appear covered by fruiting bodies (Moral et al. 2010, 2015; Michailides et al. 2015). In both olive and walnut trees, viable pycnidiospores and ascospores can also be found in attached or fallen cankered branches.

Water-dispersed pycnidiospores. Under humid conditions, pycnidia of Botryosphaeriaceae species exude a hyaline (or dark) and viscous matrix, called a cirrhus, whose pycnidiospores are spread mainly by splashing rain but also by sprinkler irrigation, insects, animals, and tools (Ahimera et al. 2004; Michailides 1991; Michailides and Morgan 1993, 2016). The spread of pycnidiospores can occur at any time during the growing season, causing primary or secondary infections. Under natural conditions, rainfall of at least $16 \mathrm{~mm}$ is needed to release pycnidiospores in cirrhi of Neof. mediterraneum (Morgan et al. 2009). The rainwater splashing or dripping from severely affected pistachios can contain up to $6 \times 10^{4}$ pycnidiospores per ml (Ahimera et al. 2004).

The number of pycnidiospores disseminated during rain events has been represented by one- or two-phase exponential decay curves since most spores are released soon after the onset of rain. Cirrhi are not exuded during dry periods because they require hydration to develop. For example, most pycnidiospores of Neof. mediterraneum are released within the first hour after the onset of rain or irrigation (Michailides and Morgan 1993). "Power law" or "negative exponential law" models (Campbell and Madden 1990) were used by Ahimera et al. (2004) to describe the dispersion gradient of Neof. mediterraneum from pistachio branches.

Aerially dispersed ascospores. Sexual reproduction has been little studied in the Botryosphaeriaceae. The type of sexual reproduction is not clear but may include homothallism (self-compatibility) in some species (Marsberg et al. 2017; Slippers and Wingfield 2007) and heterothallism (self-sterile, i.e., compatible strains in different isolates) in others (Bihon et al. 2014). In California, pseudothecial stages of $B$. dothidea and Neof. parvum have been detected on symptomatic almond and olive branches (Chen et al. 2014b; Inderbitzin et al. 2010; Moral et al. 2010). In Andalusia, Spain, $1.1 \%$ of Neof. mediterraneum fruiting bodies developing in cankered olive branches were pseudothecia (Moral et al. 2015). Because pseudothecia develop from November to December on affected olive branches, it explains the early (during February) appearance of the first disease symptoms in orchards of this region (Moral et al. 2015). In California, 1.8\% of the fruiting bodies that

Table 2. Characteristics of diseases caused by Botryosphaeriaceae species affecting almond, pistachio, walnut, and olive

\begin{tabular}{|c|c|c|c|c|c|c|c|c|}
\hline \multirow[b]{2}{*}{ Host (species) } & \multirow[b]{2}{*}{ Disease } & \multirow[b]{2}{*}{ Main pathogens (total species) } & \multicolumn{6}{|c|}{ Symptoms } \\
\hline & & & Trunk & Branch & Gumming & Bud & Leaf & Fruit \\
\hline \multirow[t]{2}{*}{$\begin{array}{l}\text { Almond (Prunus } \\
\text { dulcis) }\end{array}$} & $\begin{array}{l}\text { Band canker (canker of the } \\
\text { trunk and scaffold branches) }\end{array}$ & $\begin{array}{l}\text { Botryosphaeria dothidea, } \\
\text { Neofusicoccum parvum (13) }\end{array}$ & +++ & +++ & +++ & - & - & - \\
\hline & Lower limb dieback & B. dothidea (2) & - & +++ & - & - & - & - \\
\hline $\begin{array}{l}\text { Pistachio (Pistachia } \\
\text { vera) }\end{array}$ & $\begin{array}{l}\text { Botryosphaeria panicle and } \\
\text { shoot blight }\end{array}$ & Neof. mediterraneum & + & +++ & - & ++ & ++ & ++ \\
\hline $\begin{array}{l}\text { Walnut (Juglans } \\
\text { regia) }\end{array}$ & $\begin{array}{l}\text { Botryosphaeria canker } \\
\text { and blight (Melaxuma) }\end{array}$ & $\begin{array}{l}\text { Lasiodiplodia citricola, } \\
\text { Neof. parvum (10) }\end{array}$ & +++ & +++ & - & + & - & ++ \\
\hline \multirow[t]{2}{*}{ Olive (Olea europaea) } & Branch dieback & Neof. mediterraneum (20) & + & +++ & - & - & - & + \\
\hline & Escudete (Dalmatian disease) & B. dothidea (1) & - & - & - & - & - & + \\
\hline \multicolumn{9}{|c|}{ (Continued on next page) } \\
\hline
\end{tabular}


developed in walnut branches cankered by Botryosphaeriaceae species were pseudothecia of unknown species (most likely of $B$. dothidea; Michailides et al. 2014).

Production of ascospores has several epidemiological implications. A higher level of genotypic diversity is expected in pathogen populations with sexual recombination than exclusively asexual populations (McDonald and Linde 2002), as well as a greater dissemination capacity than conidia since ascospores can be carried by both splashing and air currents. For pycnidiospores, however, weather parameters such as intensity, amount, and duration of rainfall and velocity and turbulence of wind can affect the dispersal capacity of ascospores (Mahaffee and Stoll 2016).

Vectoring by insects. Olive escudete is the most notorious disease that includes interaction between Botryosphaeriaceae species and insects. In 2013, Eldesouki-Arafat showed that B. dothidea is spread by the midge Prolasioptera berlesiana (Diptera: Cecidomyiiddae: Lasiopterini). The female of this cecidomyiid species has a special structure called a mycangium in the abdomen that is adapted to transport B. dothidea spores (Eldesouki-Arafat 2013; Moral et al. 2016). Mycangia are characteristic of mutualistic interactions between midges and fungi (Bissett and Borkent 1988; Heath and Stireman 2010). The midge is attracted by ovipositor punctures on the fruit surface made by the olive fly (Bactrocera oleae) and deposits its own eggs adjacent to the fly's eggs, thereby also inoculating the fungus into the puncture. The cecidomyiid larvae feed on $B$. dothidea mycelium in false punctures (no oviposition, so no fly egg present) made by the fly, ostensibly to avoid predation by the cecidomyiid larvae (Eldesouki-Arafat 2013; Moral et al. 2016). The first symptoms of escudete are frequently observed in the first half of August, during the period of fly punctures (Eldesouki-Arafat 2013). This mutualistic interaction of B. dothidea with $P$. berlesiana explains why this weakly virulent fungal species is the sole causal agent of the disease (Moral et al. 2016). Although the olive fly appeared in California in 1998 (Rice et al. 2006) and $B$. dothidea and the susceptible cultivars are also present, the absence of $P$. berlesiana explains the absence of escudete in the state.

Pistachios in California are sometimes severely damaged by hemipteran species, such as Leptoglossus clypealis and Thyanta pallidovirens, which puncture the nuts, causing abortion of fruitlets, epicarp lesion, or kernel necrosis (Michailides and Morgan 2016). Of these hemipteran species, around $30 \%$ of Thyanta stinkbugs carry propagules of Neof. mediterraneum externally on their body, while this percentage ranges from 1 to $11.8 \%$ in the case of Lep. clypealis. In this latter species, the pathogen can also be isolated from excrement samples, which points to the possibility of an internal spread of the pathogen in the digestive system of the insect (Michailides and Morgan 2016).

Machinery and tools. Botryosphaeriaceae species can be spread via contaminated pruning tools (e.g., shears and saws) and other equipment. In California, we have frequently isolated species of this family from pruning wounds in pistachio and walnut orchards severely affected by cankers and branch dieback. Likewise, the clamps of trunk shakers are also a potential source of infection for almonds that often suffer cankers in the trunk. When hedging of walnuts or pistachios is done, the pruning saws can cut through branches covered with pycnidia and inoculate the wounds in healthy ones (Michailides et al. 2015). The canopy-contact harvesters, used in the hedgerow orchards, are a potential spreading vehicle within and among orchards. The dispersion of Botryosphaeriaceae inoculum by tools and equipment could explain the aggregated pattern of affected almond or olive trees growing into the same row that is often observed (Moral and Michailides, unpublished data).

Infected nursery plants. Botryosphaeriaceae species can cause symptomless (latent) infections in young plants that are readily dispersed in nursery shipments. The species $D$. seriata, $L$. citricola, $L$. theobromae, and $N$. dimidiatum impact pistachio and walnut plants in nurseries (Chen et al. 2013a, 2013b; Swart and Botes 1995). For potted plants, the presence of soil increases the risk of dispersion of soilborne pathogens such as M. phaseolina.

\section{Preinfection, Infection, and Colonization}

Once pycnidiospores or ascospores land on susceptible tissues of a host, they trigger several preinfection processes such as adhesion, spore germination, and host recognition (Sammonds et al. 2016). Temperature, water potential, and the presence of antagonistic microorganisms can delay or inhibit spore germination (Chen et al. 2003). During this process, the hyaline and aseptate Fusicoccum-like pycnidiospores may develop one or two septa and become pale brown. In some cases, Botryosphaeriaceae spp. can develop an appressorium that facilitates mechanical penetration of host tissue (Kim et al. 1999). The pathogens frequently produce enzymes, which help to break down the cuticle and cell walls, and toxins (botryosphaerans, isosclerone, and tyrosol) that aid colonization (Andolfi et al. 2011; Esteves et al. 2014). Botryosphaeriaceae species can also cause infection directly through natural openings such as stomata and lenticels (Kim et al. 1999; Michailides 1991).

The presence of wounds facilitates infection, and severe symptoms are often associated with different types of wounds on lignified and green tissues (Michailides 1991; Michailides and Morgan 2004; Moral et al. 2017b). In almond band canker, plant infection occurs through growth cracks that serve as entryways of infection (Fig. 3A). Almond infection can also occur through wounds on fruit and peduncles as well as cracks at the base of shoots and scaffold branches due to wind damage and pruning wounds. Aggressive cankers are often initiated from major pruning cuts and can ultimately

Table 2. (Continued from previous page)

\begin{tabular}{|c|c|c|c|c|c|}
\hline \multicolumn{2}{|c|}{ Inoculum } & \multicolumn{2}{|r|}{ Insect Role } & \multirow[b]{2}{*}{ Epidemiologist characteristics } & \multirow[b]{2}{*}{ Control } \\
\hline Pycniospores & Ascospores & Vectors & Inductor & & \\
\hline+++ & + & - & - & $\begin{array}{l}\text { Mono or oligocyclic pathogen, } \\
\text { polyetic epidemic }\end{array}$ & $\begin{array}{l}\text { Irrigation management; timely } \\
\text { pruning }\end{array}$ \\
\hline+++ & $?$ & - & - & - & Irrigation management \\
\hline+++ & - & - & $\begin{array}{l}\text { Thyanta pallidovirens, } \\
\text { Acrosternum hilare, } \\
\text { Leptoglossus clypealis, } \\
\text { Palumbina gerinii }\end{array}$ & $\begin{array}{l}\text { Mono or oligocyclic pathogen, } \\
\text { polyetic epidemic }\end{array}$ & $\begin{array}{l}\text { Irrigation management; selective } \\
\text { pruning; control of stinkbugs; } \\
\text { chemical sprays }\end{array}$ \\
\hline+++ & + & - & Quadraspidiotus juglansregiae & $\begin{array}{l}\text { Mono or oligocyclic pathogen, } \\
\text { polyetic epidemic }\end{array}$ & $\begin{array}{l}\text { Selective pruning; irrigation } \\
\text { management; control walnut } \\
\text { scale; chemical sprays }\end{array}$ \\
\hline+++ & ++ & - & - & $\begin{array}{l}\text { Mono or oligocyclic pathogen, } \\
\text { polyetic epidemic }\end{array}$ & $\begin{array}{l}\text { Selective pruning cultivars } \\
\text { different than 'Gordal } \\
\text { sevillana'; chemical sprays }\end{array}$ \\
\hline+++ & - & $\begin{array}{l}\text { Prolasioptera } \\
\text { berlesiana }\end{array}$ & Bactrocera olea & Interaction fly-mosquito-fungus & $\begin{array}{l}\text { Control olive fly (Bactrocera } \\
\text { oleae); cultivar resistance }\end{array}$ \\
\hline
\end{tabular}


kill trees. Wounding caused by Hemipteran insects exacerbates fruit infection, resulting in a high severity of disease in California pistachios (Michailides and Morgan 2016). Sap that oozes onto the epicarp after fruit puncturing favors spore germination and growth of Neof. mediterraneum by providing the needed moisture and nutrients. However, once the sap dries it can protect the wound against subsequent infections (Moral et al. 2017b).

In walnut, pathogen infection occurs either directly in wounded or nonwounded hulls or through wounds and scars caused by fruit and leaf peduncles (Michailides et al. 2013). The infection and colonization of shoots and spurs of walnut are distinctive because colonization frequently begins in the husk of one fruit, spreads to adjacent fruits, colonizes the peduncle, and then moves into the spur and shoot, causing canker and blight (Michailides et al. 2014; Fig. 5D). Walnut branches are characterized by the presence of brownish segmented pith, which facilitates and advances the longitudinal colonization of the branches by the pathogen. Pith infection can occur up to $5 \mathrm{~cm}$ in advance of colonization of woody tissues. Infections then move into the tissues surrounding the pith and subsequently extend into the xylem (Agustí-Brisach et al. 2019).

\section{Saprophytic Phase}

Botryosphaeriaceae species can colonize dead tissues such as the outer bark of trunks of nut crops and other perennial woody crops; old cankers caused by Botrytis cinerea in pistachios; or shoots and branches killed by Verticillium dahliae or Phytophthora spp. in almonds, pistachios, and olive. In California orchards, Botryosphaeriaceae species and the bacterium Xanthomonas arboricola pv. juglandis are often isolated together from necrotic lesions on walnut fruit, suggesting that the bacterium can enter through the stylar end and cause necrosis, after which the fungus may follow (Michailides et al. 2014). The pathogen can colonize other dead tissues (i.e., branches killed by branch wilt in walnut) and branches and shoots pruned and left on the ground. This saprophytic ability could explain why Botryosphaeriaceae species are readily isolated from healthy pistachio and almond branches in California.

\section{Epidemiology}

Botryosphaeriaceae species are monocyclic or oligocyclic pathogens that cause polyetic epidemics. As monocyclic pathogens, they complete one disease cycle, or even part of one, in one season. Depending on the weather conditions, these species can be oligocyclic pathogens, i.e., polycyclic pathogens with a few (two or three) disease cycles per season. In both cases, epidemic development and symptom severity are largely dependent on initial inoculum (Table 2). In polyetic epidemics, inoculum generated during one season contributes to primary inoculum during the next season (Zadoks and Schein 1979). For this reason, the time course of epidemics of diseases caused by Botryosphaeriaceae species may extend for several successive years.

\section{Factors Influencing Disease Development}

Weather parameters. Infections in olives, pistachios, and walnuts can occur at any time during the season if there is splashing water and suitable temperatures $\left(10\right.$ to $\left.35^{\circ} \mathrm{C}\right)$ to induce spore germination (Ahimera et al. 2003; Michailides and Morgan 1992, 1993, 2004; Moral et al. 2010). Pycnidiospore germination and germ tube elongation require free water or relative humidity $\geq 90 \%$ (Arauz and Sutton 1989; Ma et al. 2001). Temperatures of 25 to $30^{\circ} \mathrm{C}$ are

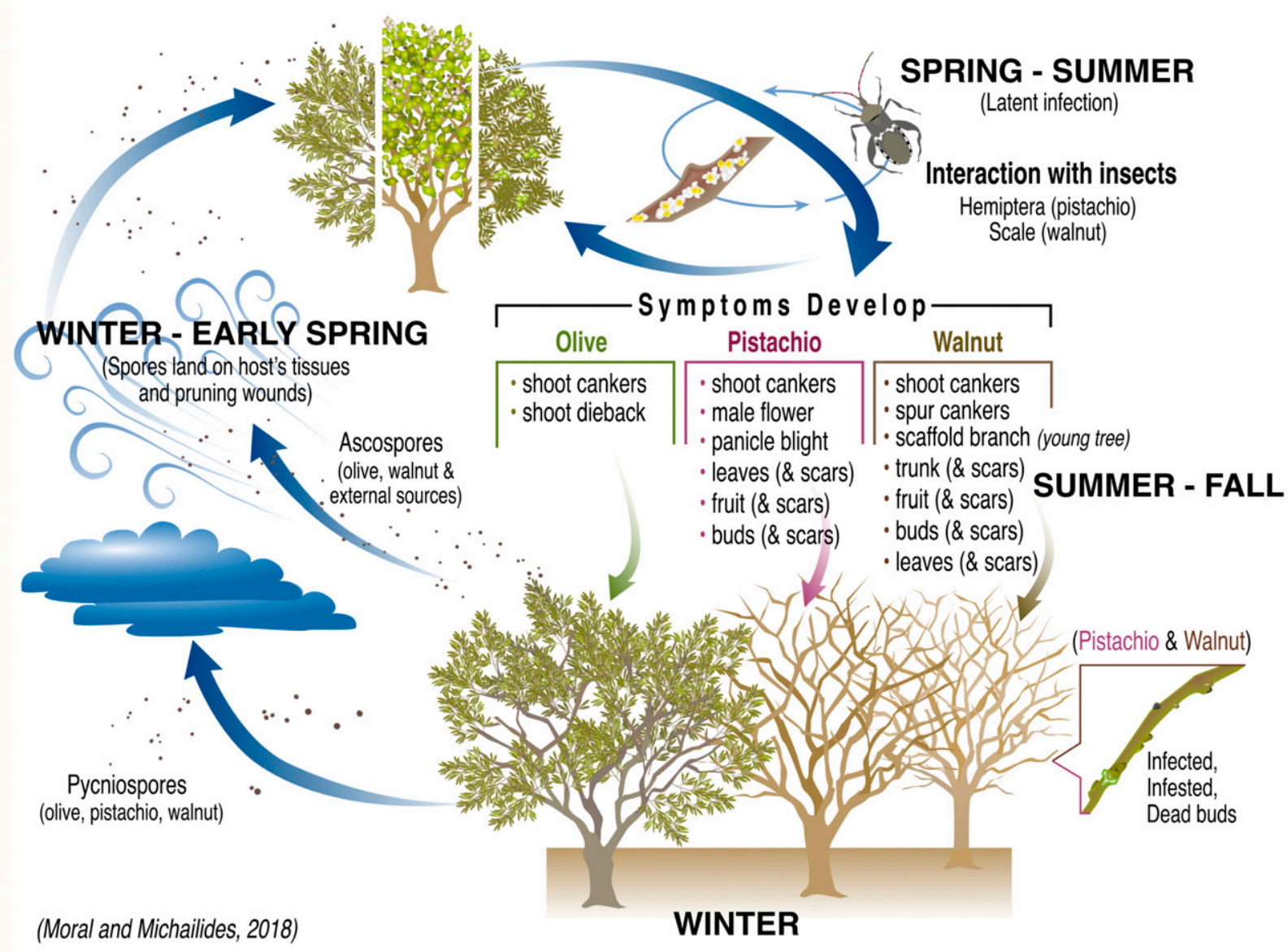

Fig. 9. Disease cycles of Botryosphaeria panicle and shoot blight of pistachio, Botryosphaeria and Phomopsis canker and blight of walnut, and olive dieback of branches caused by Neofusicoccum mediterraneum. 
considered optimal for spore germination, but optima vary among species, isolates within species, and spore type (Copes and Hendrix 2004; Michailides and Morgan 1992; Úrbez-Torres et al. 2010). For example, both Spanish and Greek isolates of $B$. dothidea causing escudete showed an optimum of $30^{\circ} \mathrm{C}$ for conidial germination, suggesting that the pathogen is well adapted to high summer temperatures. However, germination of spores was almost nil at $35^{\circ} \mathrm{C}$ for Greek isolates and at $45^{\circ} \mathrm{C}$ for Spanish isolates (Moral et al. 2010; Zachos and Tzavella-Klonari 1979). Similarly, pycnidiospores of Neof. mediterraneum isolates from pistachio that germinated at $>36^{\circ} \mathrm{C}$ frequently failed to develop colonies (Michailides and Morgan 1992). Dry periods occurring between wet periods can also affect spore germination (Arauz and Sutton 1990). For example, alternating wet with dry periods during germination of spores of Neofusicoccum spp. resulted in development of 2 to 3 septa in the spores and brown coloration (Michailides 1991). Temperature and humidity also influence pycnidia, whose numbers increased linearly in
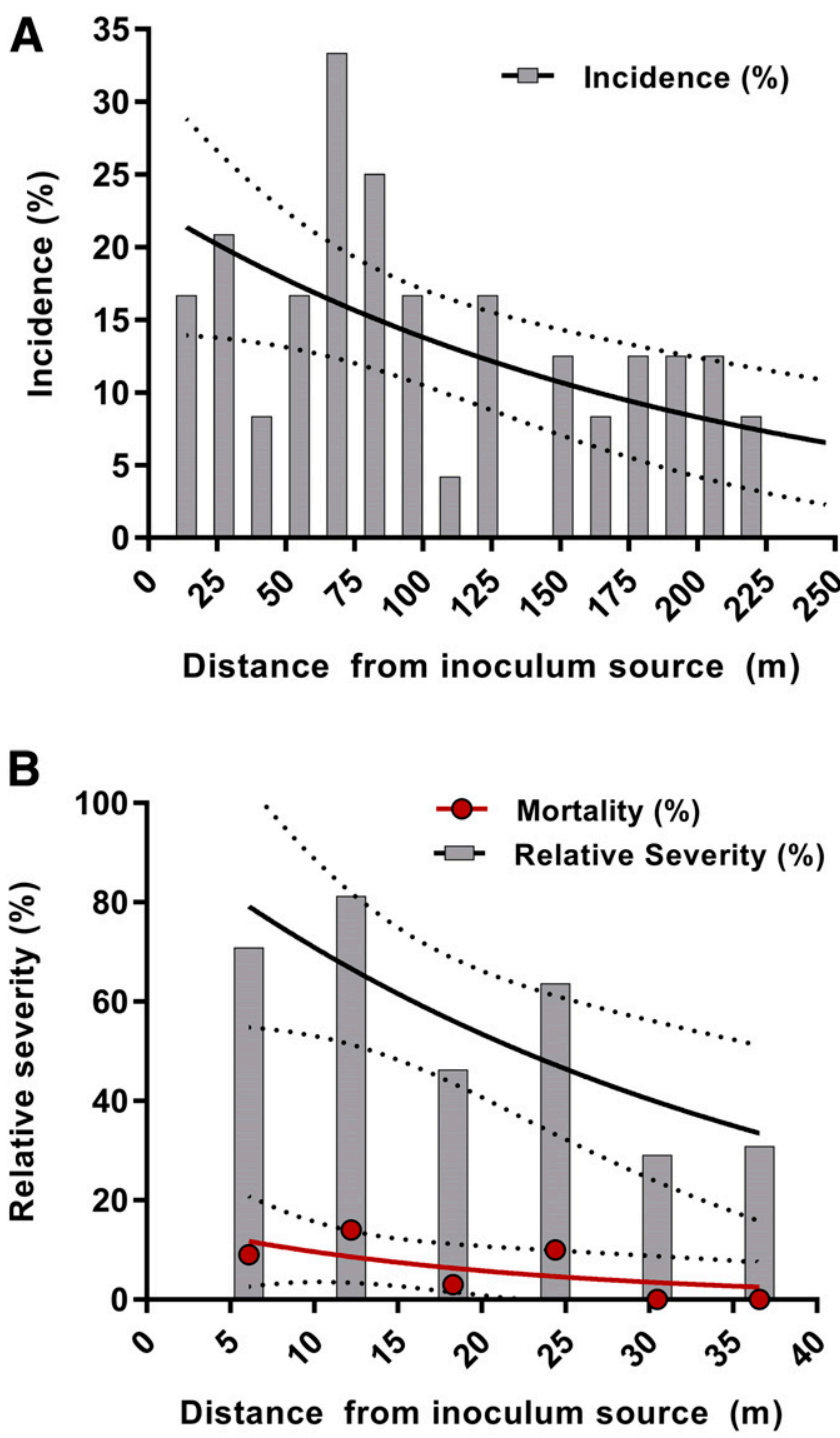

Fig. 10. Relationship between distance $(\mathrm{m})$ from inoculum source and the incidence or severity of symptoms of almond band canker caused by Botryosphaeriaceae species. Incidence of band canker in a third-leaf almond orchard at difference distances from an irrigation canal and the riparian vegetation providing the inoculum source of the pathogen (A). Relative severity of symptoms (\%) and mortality (\%) due to band canker in a fifth-leaf almond cv. Nonpareil orchard almond orchard as affected by distance from a walnut orchard that served as the inoculum source of the pathogen (B). The line represents the exponential models $(S=a \times b D)$ relating severity (S) of symptoms to distance (D) from the inoculum source. Dashed lines represent confidence intervals at $95 \%$. affected branches as temperature increased from 10 to $35^{\circ} \mathrm{C}$ (Michailides and Morgan 1992). High temperatures are also associated with symptom expression. For example, in pistachio, the first blighted symptoms usually appear with the increase of temperature at the end of spring or beginning of summer, when panicle collapse can occur in a few weeks (Michailides and Morgan 1992; Mila et al. 2005; Moral et al. 2017b). Light intensity and duration also affect pycnidia development and pathogen sporulation, but these relationships are poorly understood.

Inoculum potential: inoculum density and pathogen virulence. Botryosphaeriaceae species exhibit substantial differences in virulence (Table 1). Also, the inoculum density of Botryosphaeriaceae species at a given time depends on the period of the season (Ahimera et al. 2004; Moral et al. 2017b) and on the final disease severity during the previous season. Fungicide residues and antagonist microorganisms over the plant surface also affect the inoculum potential by altering the spores' viability. The distance to other hosts (i.e., donors of spore inoculum) can have a substantial impact on local inoculum density and therefore the spatial pattern of disease incidence. For example, in almond orchards affected by band canker, the severity of symptoms declined with distance from external inoculum sources (Fig. 10; Michailides et al. 2018). In sum, the spatial pattern of disease severity in a given plot is a combined effect of internal inoculum, distance to the external inoculum sources, and edge effect.

Plant susceptibility. With almond band canker, the main period of infection seems to be during the spring when moderate temperatures and rain are present or sprinkler irrigation water wets the trunks of trees (Michailides et al. 2009). During this season, rapid radial growth of the almond trunk frequently causes growth cracks. In inoculation tests, young almonds are susceptible to infection by $B$. dothidea across the entire season, but cankers develop and grow fastest in the early spring (Michailides et al. 2009, 2018). In the case of pistachio shoots, susceptibility decreases across the season as lignification proceeds (Michailides 1991). In contrast, susceptibility of pistachio buds to infection increases exponentially from mid-February (dormant buds) to mid-March (swelling to expanding buds) (Michailides and Morgan 2004). Susceptibility of pistachio nuts increases from May to late July, when the kernel has almost reached its full size, then decreases until it reaches a level similar to that during spring (Mila et al. 2005; Ntahimpera et al. 2002). Vigorous walnut shoots are resistant to pathogen infection during the spring when there is a high accumulation of phenols. Similarly, walnut spurs show high resistance to pathogen infection during May, then increasing susceptibility from June to the end of August. In field experiments, inoculation of immature and maturing walnut nuts later resulted in blighted fruit (Michailides et al. 2015). However, when the

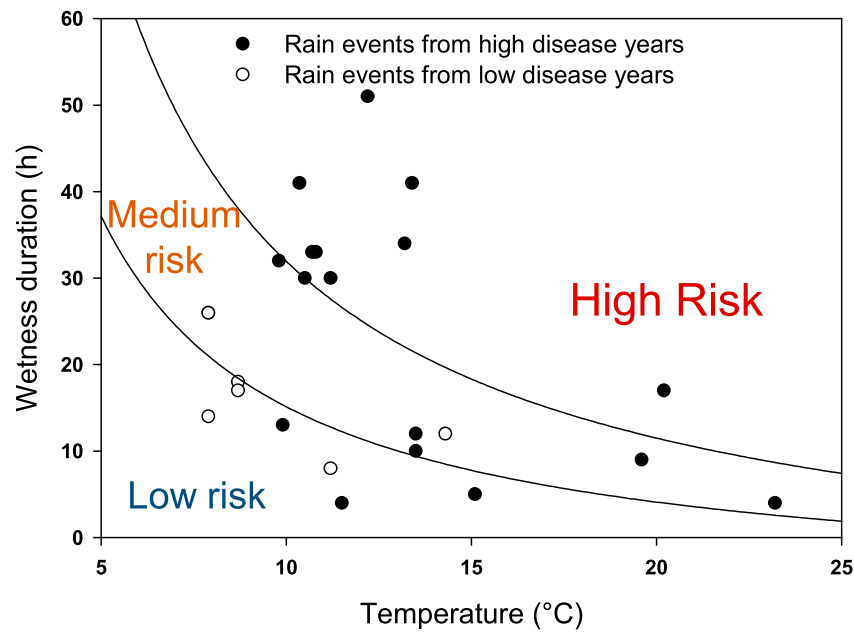

Fig. 11. Relative risk of infection of pistachio fruit by Neofusicoccum mediterraneum as determined by the wetness period $(\mathrm{W})$ events and temperature $(\mathrm{T})$. Wetness periods are calculated by combining $\leq 12 \mathrm{~h}$ of dry periods initiated by rain events with $\geq 4 \mathrm{~mm}$ of rain per event as recorded by electronic wetness sensors. 
inoculations were conducted in August and September, the incidence of fruit blight was higher (Michailides et al. 2014). This temporal pattern suggests that autumn infections can result in more damage to walnut nuts because these infections have a higher probability of causing fruit blight and decay of kernels than infections initiated in the spring. In olive fruit, developing drupes are almost immune to Botryosphaeria infection due to an ontogenic resistance to infection that correlates with rising levels of phenolic compounds during fruit development (Moral et al. 2010, 2019).

The factors that trigger symptom development in plant tissues with latent infection of Botryosphaeriaceae species are unknown, although nutritional (i.e., increase in carbohydrates), weather (i.e., temperature increase), and host factors (i.e., drought stress), as well as changes in the dynamics and densities of antifungal compounds (i.e., specific phenolic compounds) on the green tissues and fruit, have been reported to induce symptom development (Ma et al. 2001; Michailides and Morgan 1992; Ntahimpera et al. 2002).

Soil properties. Excessively wet soil conditions during the spring, which can decrease the amount of oxygen available for the roots, followed by a rapid decline of the soil water content, may play a primary role in defoliation and loss of viability of almond branches in the lower half (LLDB) of tree canopies (Lampinen et al. 2009). Subsequently, Botryosphaeria and Phomopsis species can act as secondary pathogens or saprophytes affecting branches weakened by soil water stress (Michailides et al. 2009).

Insects. The population of Hemipteran insects on pistachio panicles was directly correlated with symptom severity caused by Neof. mediterraneum (Michailides and Morgan 2016). Likewise, high severity of walnut Botryosphaeria canker and blight was associated with high density of walnut scale (Quadraspidiotus juglansregiae), since severe damage by scale predisposes walnut shoots to disease (Michailides et al. 2013, 2014). As one might expect considering the disease cycle of olive "escudete", higher Bactrocera fly populations (and after that, higher incidence of oviposition punctures on fruit caused by female flies) resulted in more severe outbreaks of $B$. dothidea-incited symptoms (Eldesouki-Arafat 2013; Moral et al. 2016).

\section{Disease Forecasting}

Because the severity and economic impact of Botryosphaeriaceae diseases differ substantially among seasons-years with epidemics often alternate with years during which symptoms are few or absent - these diseases are suitable candidates for forecasting. Disease forecasting enables farmers to use host, pathogen, and environmental conditions to help them determine when to initiate disease management actions. In this way, disease forecasting can help to reduce the use of pesticides by farmers.

Forecast based on primary infection. Initial efforts to provide a forecast scheme for pistachio panicle and shoot blight were focused on primary infection by the pathogen. These models were based on the knowledge that buds can be infested/infected during the previous

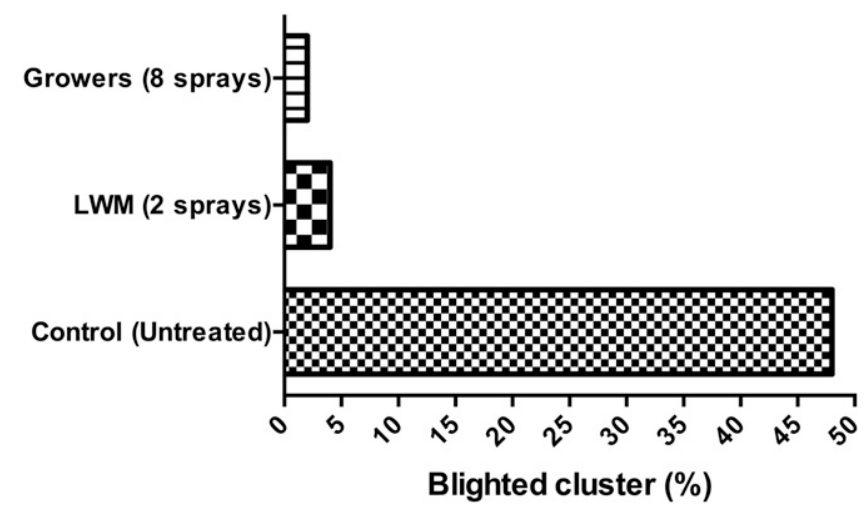

Fig. 12. Incidence of blighted clusters of pistachio caused by Neofusicoccum mediterraneum as affected by the grower's calendar-timed spray schedule (eight fungicide sprays per season), or according to the leaf wetness model (LWM, two fungicide sprays per season), and untreated control trees. season, and that early infections of developing fruit during spring remain latent until later in the growing season. According to the BUDMON (bud monitoring) model, split or intact buds collected at the end of winter are plated on culture media to quantify the percentage of affected buds, which is linearly correlated with the final severity of symptoms (Michailides and Morgan 2004; Ntahimpera et al. 2002). In old plantings, BUDMON provides a preseason prediction of disease risk, whereas in young plantings it determines when an orchard that was formerly free of Botryosphaeria starts showing invasion by the pathogen, which triggers annual monitoring to avoid major losses (Michailides and Morgan 2004). After finding that walnut buds are too infested/infected by Botryosphaeriaceae, we applied the BUDMON bioassay to determine whether predicted Botryosphaeria canker and blight of walnut (Michailides et al. 2013, 2014). Although the BUDMON bioassay is successful in predicting final disease severity, weather conditions after bud sprouting, which are not taken into account by BUDMON, impact symptom severity affecting the accuracy of this method (Mila et al. 2005; Morgan et al. 2009).

From mid-June to early July, the overnight freezing-incubation technique (ONFIT) provides a useful forecast of end-of-season infection intensity of pistachio panicle and shoot blight. The percentage of latent infections in developing pistachio nuts or leaves is detected by incubation of previously frozen developing fruit in humid chambers (Michailides and Morgan 2004). Because ONFIT provides quantification of latent infection during the spring and early summer, and later rainfall events are very sporadic in Mediterranean conditions, this technique frequently offers a better forecast of the final disease intensity than BUDMON. However, ONFIT can underestimate final disease incidence in years with few latent infections but unusually disease-favorable environmental conditions during summer (Morgan et al. 2009).

Forecast based on weather parameters. Pistachio panicle and shoot blight is impacted by rainfall during the spring, which favors latent infections, and cumulative temperature during the summer, which can trigger symptom development (Mila et al. 2005; Mila and Michailides 2006). We developed a simple degree-day model for summer in which accumulation of $40 \mathrm{~h}$ of $\geq 32^{\circ} \mathrm{C}$ was effective for decision-making in years with relatively few rain events (Mila et al. 2005). The Botryosphaeria infection model (BIM), which considered that pathogen infection occurs when the temperature is $\geq 11^{\circ} \mathrm{C}$ and rainfall of $\geq 1 \mathrm{~mm} / \mathrm{h}$ occurred for $\geq 4 \mathrm{~h}$ (Michailides and Morgan 2004), was superseded by the leaf wetness model (LWM), which also uses temperature as an independent variable, and replaces rainfall variables by wetness duration (Morgan et al. 2009; Fig. 11). This LWM is popular with California pistachio farmers since it enables effective control of the disease with a reduced number of early-season sprays (Morgan et al. 2009; Fig. 12).

BUDMON and LWM can be combined to improve disease risk assessment accuracy (Morgan et al. 2009). Also, the ONFIT method estimates the incidence of latent infections and aids decision-making for application of fungicides. The initial results of the application of LWM for managing Botryosphaeria canker and blight of walnut were very promising (Michailides et al. 2015).

Forecast based on host phenology or vectors. For hosts, which show a short period of peak susceptibility, the final level of the disease can be estimated according to weather conditions and inoculum quantity during that period. Consequently, fungicide treatments should be applied during this time. Working with apples, Smith and Hendrix (1984) showed that applying a fungicide during the silver-tip stage, which is the most susceptible to black rot caused by $D$. seriata, reduced five sprays of fungicides per season to only one spray.

Finally, in the case of olive escudete, for which olive fly punctures are a prerequisite for infection (Eldesouki-Arafat 2013; Moral et al. 2016), the disease forecast could be based on risk models developed for olive fly (Ponti et al. 2014).

\section{Disease Control}

Control of Botryosphaeriaceae species affecting perennial crops requires an integrated approach (reviewed by Moral et al. 2019). Tree density and canopy management practices that provide good 
ventilation and sunlight exposure decrease infection risk and symptom severity. Pruning should eliminate dead tissues or affected ones bearing fruiting bodies of the pathogens in order to reduce inoculum. Prunings left on the orchard ground, as well as almond stumps left after removal of trees killed by band canker, should be eliminated by chipping or burning.

Irrigation practices minimize wetting of the trunk or canopy. In pistachio, Michailides and Morgan (1993) reduced the incidence of blighted cluster from 92 to $21 \%$ using sprinklers of low-trajectory angle, which minimized trunk and canopy wetting, rather than sprinklers with a high-trajectory angle (Fig. 13). In the case of the almond LLDB disorder, the farmers should avoid over-irrigation during the spring (Lampinen et al. 2009).

No almond, pistachio, or walnut cultivars are known to be completely resistant to species of Botryosphaeriaecae, but some differences have been described. For example, the branches of the common pistachio cvs. Kerman and Lost Hills are susceptible to the pathogen, whereas their fruit show a high level of resistance to these species (Moral et al. 2019). The most important differences have been described among olive cultivars. For example, cv. Gordal Sevillana shows a marked susceptibility to Neof. mediterraneum under artificial and natural infections (Moral et al. 2017a), as well as to escudete, in comparison with other cultivars (Hojiblanca and Picual) under field conditions. Substantial cultivar differences of fruit susceptibility to escudete have been described in Spain and Montenegro (Latinović et al. 2013; Moral et al. 2017a), although differences in cultivar attractiveness to olive fly could have an important role in the percentage of diseased fruit.

In general, the use of different Trichoderma strains to control Botryosphaeriaceae species affecting pistachio crop has failed. However, other microbiological control organisms, including yeast and bacteria, should be evaluated. Conversely, a good number of different classes of synthetic fungicides, including some premixes of strobilurins and carboxamides, have shown excellent efficacy in field conditions to control of pistachio panicle and shoot blight (Adaskaveg et al. 2017). In this latter disease, spray applications should be conducted at early bloom and be repeated in early summer (Michailides and Morgan 2004). However, for growers to be accurate and effective with the sprays, they can spray according to advisories from LWM in pistachio and walnut orchards (Morgan et al. 2009). In the case of olive, fungicides should be applied after harvest to protect the numerous wounds caused by the harvesters, and at the end of the winter when mature ascospores are frequently found (Moral et al. 2015, 2019). In the case of escudete, control of the olive fly is the most efficient management measure against the

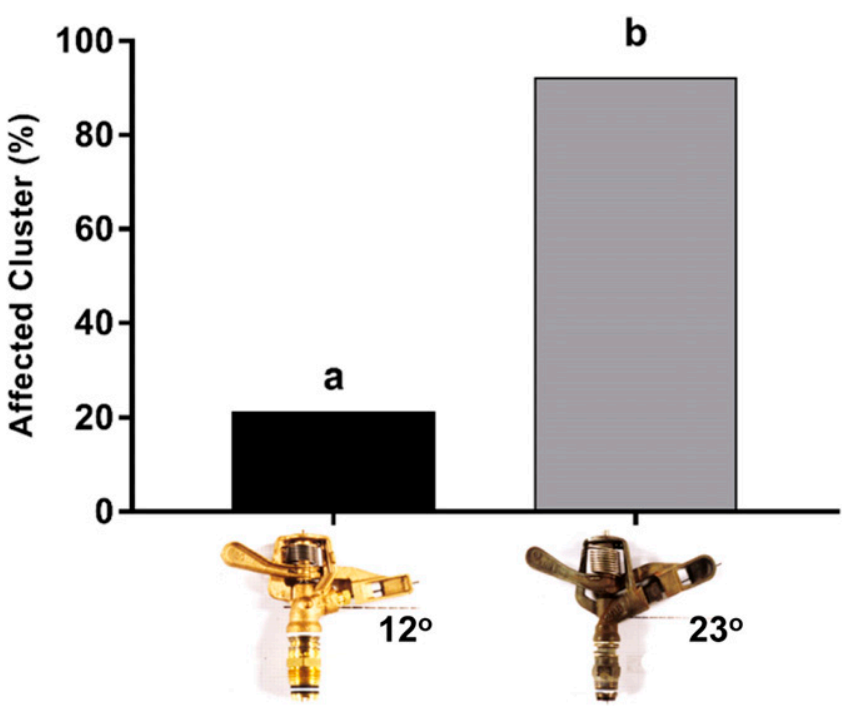

Fig. 13. Effect of irrigation using sprinklers with two different trajectory angles on the incidence of pistachio blighted clusters caused by Neofusicoccum mediterraneum. Means with different letters are significantly different according to Student's $t$ test at $P=0.05$. fungal pathogen (Eldesouki-Arafat 2013). It should be noted that the introduction of $P$. berlesiana as a predator of fly eggs in olive fly-free areas could also suppress disease development.

\section{Current Challenges and Future Prospects}

There are considerable challenges in advancing our knowledge of etiology of Botryosphaeriaceae diseases affecting nut and olive crops, but less is known about their epidemiology and ecology. Regarding etiology, interaction (competition, neutral, or synergistic) among the various species in a given host has scarcely been studied. Such studies could help us understand sign development and symptom expression on the tree. Although the sexual state of certain members of Botryosphaeriaceae was found naturally occurring on almond and walnut, in general, the role of sexual reproduction under field conditions has not been studied. Methods for obtaining sexual fruiting bodies and ascospores of these species could help us to understand this role and to characterize the type of sexual reproduction on the members of this family. In growing areas where sexual stages are known, distribution of mating-type genes (MAT) is an excellent approach to understanding the equilibrium of the pathogen population. There is a limited knowledge of the impact of Botryosphaeriaceae diseases on yield and economic losses, although before the development of effective chemical control, Botryosphaeria panicle and shoot blight of pistachio resulted in $100 \%$ crop loss in some orchards. Standard protocols of stock plant management to avoid infected plant distribution, ensuring the health plant status during the first years after plantation and pathogen spread, are becoming ever more necessary considering the global movement of plant material. Advances in our understanding of the "susceptibility window" of the different plant tissues (e.g., developing olive and walnut fruit(s) and growing walnut shoots) according to the dynamics of antifungal compounds are essential to identify optimum time period for treatment. Similarly, the impacts of biotic and abiotic stresses on plant predisposition to Botryosphaeriaceae species and interactions with members of Diaporthaceae are crucial in understanding complex situations, such as the decline of mature walnut orchards or LLDB of almond. Furthermore, biotic stresses are clearly associated with a change of lifestyle of these species, but this phenomenon has been little explored. In the case of almond band canker, members of Botryosphaeriaceae transition from a saprophytic stage on the bark to a pathogenic stage in the trunk wood. Clearly, a main challenge in research on olive "escudete" is how to identify when female cecidomyiid flies acquire spores of $B$. dothidea. California pistachio and walnut growers have benefited greatly by the use of BUDMON and LWM for reducing the number of fungicide applications while maintaining good control of Botryosphaeriaceae species on both crops. However, LWM should be validated in other nut-growing areas before its use. The development of robust mechanistic models that consider the different steps of the disease cycle will help the process of validation in these areas. Finally, controlled studies on combining cultural and chemical practices based on the dominant Botryosphaeriaceae species on each nut/olive-producing area merits investigation for improving the management of Botryosphaeria diseases.

\section{Acknowledgments}

Thanks to Mr. D. Cabello and Dr. C. M. Díez for giving us photos for figures 1D and 7D, respectively. We would like to dedicate this work to the model farmers Ioannis Michailides and Vicente Moral.

\section{Literature Cited}

Abdollahzadeh, J., Zare, R., and Phillips, A. J. 2013. Phylogeny and taxonomy of Botryosphaeria and Neofusicoccum species in Iran, with description of Botryosphaeria scharifii sp. nov. Mycologia 105:210-220.

Adaskaveg, J. E., Gubler, D., and Michailides, T. 2017. Fungicides, bactericides, and biologicals for deciduous tree fruit, nut, strawberry, and vine crops University of California Agriculture and Natural Resources. http:// ipm.ucanr.edu/PDF/PMG/fungicideefficacytiming.pdf 
Agustí-Brisach, C., Moral, J., Felts, D., Trapero, A., and Michailides, T. 2019. Interaction between Diaporthe rhusicola and Neofusicoccum mediterraneum causing branch dieback and fruit blight of English walnut in California, and effect of pruning wounds to the infection. Plant Dis. 103:11961205 .

Ahimera, N., Driever, G. F., and Michailides, T. J. 2003. Relationships among propagule numbers of Botryosphaeria dothidea, latent infections, and severity of panicle and shoot blight in pistachio orchards. Plant Dis. 87: 846-853.

Ahimera, N., Gisler, S., Morgan, D. P., and Michailides, T. J. 2004. Effects of single-drop impactions and natural and simulated rains on the dispersal of Botryosphaeria dothidea conidia. Phytopathology 94:1189-1197.

Allen, R. J., and Luptowitz, R. 2017. El Niño-like teleconnection increases California precipitation in response to warming. Nat. Commun. 8:16055.

Andolfi, A., Mugnai, L., Luque, J., Surico, G., Cimmino, A., and Evidente, A. 2011. Phytotoxins produced by fungi associated with grapevine trunk diseases. Toxins (Basel) 3:1569-1605.

Arauz, L. F., and Sutton, T. B. 1989. Influence of temperature and moisture on germination of ascospores and conidia of Botryosphaeria obtusa. Phytopathology 79:667-674.

Arauz, L. F., and Sutton, T. B. 1990. Effect of interrupted wetness periods on spore germination and apple infection by Botryosphaeria obtusa. Phytopathology 80 : 1218-1220.

Armengol, J., Gramaje, D., Pérez-Sierra, A., Landeras, E., Alzugaray, R., Luque, J., and Martos, S. 2008. First report of canker disease caused by Neofusicoccum australe on eucalyptus and pistachio in Spain. Plant Dis. 92:980.

Bihon, W., Wingfield, M. J., Slippers, B., Duong, T. A., and Wingfield, B. D. 2014. MAT gene idiomorphs suggest a heterothallic sexual cycle in a predominantly asexual and important pine pathogen. Fungal Genet. Biol. 62: 55-61.

Bissett, J., and Borkent, A. 1988. Ambrosia galls: the significance of fungal nutrition in the evolution of the Cecidomyiidae (Diptera). Pages 203-225 in: Coevolution of Fungi with Plants and Animals. K. A. Pirozynski and D. L. Hawkswort, ed. Academic Press, San Diego, CA.

Brooks, F. E., and Ferrin, D. M. 1994. Branch dieback of southern California chaparral vegetation caused by Botryosphaeria dothidea. Phytopathology 84: 78-83

Campbell, C. L., and Madden, L. V. 1990. Introduction to Plant Disease Epidemiology. John Wiley \& Sons, New York.

Carlucci, A., Raimondo, M. L., Cibelli, F., Phillips, A. J. L., and Francesco, L. O. P. S. 2013. Pleurostomophora richardsiae, Neofusicoccum parvum and Phaeoacremonium aleophilum associated with a decline of olives in southern Italy. Phytopathol. Mediterr. 52:517-527.

Cesati, V., and De Notaris, G. 1863. Schema di classificazione degle sferiacei italici aschigeri piu' o meno appartenenti al genere Sphaeria nell'antico significato attribuitoglide Persono. Commentario de lla Società Crittogamologica Italiana. 1:177-420

Chattaoui, M., Rhouma, A., Krid, S., Triki, M. A., Moral, J., Msallem, M., and Trapero, A. 2011. First report of fruit rot of olives caused by Botryosphaeria dothidea in Tunisia. Plant Dis. 95:770.

Chattaoui, M., Rhouma, A., Msallem, M., Perez, M., Moral, J., and Trapero, A. 2012. First report of Botryosphaeria obtusa as causal agent of olive tree branch dieback in Tunisia. Plant Dis. 96:905.

Chen, S. F., Fichtner, E., Morgan, D. P., and Michailides, T. J. 2013a. First report of Lasiodiplodia citricola and Neoscytalidium dimidiatum causing death of graft union of English walnut in California. Plant Dis. 97:993.

Chen, S. F., Li, G., Liu, F., and Michailides, T. J. 2015. Novel species of Botryosphaeriaceae associated with shoot blight of pistachio. Mycologia 107:780-792.

Chen, S. F., Morgan, D., Beede, R. H., and Michailides, T. J. 2013b. First report of Lasiodiplodia theobromae associated with stem canker of almond in California. Plant Dis. 97:994.

Chen, S. F., Morgan, D. P., Hasey, J. K., Anderson, K., and Michailides, T. J. 2014a. Phylogeny, morphology, distribution, and pathogenicity of Botryosphaeriaceae and Diaporthaceae from English walnut in California. Plant Dis. 98:636-652.

Chen, S. F., Morgan, D. P., and Michailides, T. J. 2014b. Botryosphaeriaceae and Diaporthaceae associated with panicle and shoot blight of pistachio in California, USA. Fungal Divers. 67:157-179.

Chen, W. Q., Morgan, D. P., Felts, D., and Michailides, T. J. 2003. Antagonism of Paenibacillus lentimorbus to Botryosphaeria dothidea and biological control of panicle and shoot blight of pistachio. Plant Dis. 87:359-365

Copes, W. E., and Hendrix, F. F. 2004. Effect of temperature on sporulation of Botryosphaeria dothidea, B. obtusa, and B. rhodina. Plant Dis. 88: 292-296.

Díez, C. M., Moral, J., Cabello, D., Morello, P., Rallo, L., and Barranco, D. 2016. Cultivar and tree density as key factors in the long-term performance of super high-density olive orchards. Front. Plant Sci. 7.

Doll, D. A., Rolshausen, P. E., and Michailides, T. J. 2013. Botryosphaeriaceae associated with almond trunk cankers: A threat to the al industry? Phytopathology 103:S12.
Doll, D. A., Rolshausen, P. E., Pouzoulet, J., and Michailides, T. J. 2015. First report of Dothiorella iberica causing trunk and scaffold cankers of almond in California. Plant Dis. 99:1185.

Eldesouki-Arafat, I. 2013. Interacciones de Batrocera oleae Gmel. (Mosca del olivo) con Botryosphaeria dothidea Moug. (Escudete de la aceituna) y de Phloeotribus scarabaeoides Bern. (Barrenillo del olivo) con Verticillium dahliae Kleb. causante de la Verticilosis del olivo. Ph.D. Thesis, University of Cordoba, Cordoba, Spain.

English, H. 1975. Relationship of Botryosphaeria dothidea and Hendersonula toruloidea to a canker disease of almond. Phytopathology 65:114-122.

Esteves, A. C., Saraiva, M., Correia, A., and Alves, A. 2014. Botryosphaeriales fungi produce extracellular enzymes with biotechnological potential. Can. J. Microbiol. 60:332-342.

Estruch, R., Ros, E., Salas-Salvadó, J., Covas, M. I., Corella, D., Arós, F., GómezGracia, E., Ruiz-Gutiérrez, V., Fiol, M., Lapetra, J., and Lamuela-Raventos, R. M. 2013. Primary prevention of cardiovascular disease with a Mediterranean diet. N. Engl. J. Med. 368:1279-1290.

Fawcett, H. S. 1915. Melaxuma of the Walnut, "Juglans regia". A Preliminary Report. No. 261

Gramaje, D., Agustí-Brisach, C., Pérez-Sierra, A., Moralejo, E., Olmo, D. Mostert, L., Damm, U., and Armengol, J. 2012. Fungal trunk pathogens associated with wood decay of almond trees on Mallorca (Spain). Persoonia 28:1-13.

Haggag, W. M., Abou Rayya, M. S. M., and Kasim, N. E. 2007. First report of a canker disease of walnut caused by Botryodiplodia theobromae in Egypt. Plant Dis. 91:226.

Heath, J. J., and Stireman, J. O. 2010. Dissecting the association between a gall midge, Asteromyia carbonifera, and its symbiotic fungus, Botryosphaeria dothidea. Entomol. Exp. Appl. 137:36-49.

Iannotta, N., Noce, M. E., Ripa, V., Scalercio, S., and Vizzarri, V. 2007. Assessment of susceptibility of olive cultivars to the Bactrocera oleae (Gmelin, 1790) and Camarosporium dalmaticum (Thüm) Zachos \& Tzav.-Klon. attacks in Calabria (Southern Italy). J. Environ. Sci. Health 42:789-793.

Inderbitzin, P., Bostock, R. M., Trouillas, F. P., and Michailides, T. J. 2010. A six locus phylogeny reveals high species diversity in Botryosphaeriaceae from California almond. Mycologia 102:1350-1368.

Kaliterna, J., Milicevic, T., Ivic, D., Bencic, D., and Mesic, A. 2013. First report of Diplodia seriata as causal agent of olive dieback in Croatia. Plant Dis. 97: 231-244.

Kim, K. W., Park, E. W., and Ahn, K. K. 1999. Pre-penetration behavior of Botryosphaeria dothidea on apple fruits. Plant Pathol. J. 15:223-227.

Kris-Etherton, P. M., Hu, F. B., Ros, E., and Sabaté, J. 2008. The role of tree nuts and peanuts in the prevention of coronary heart disease: multiple potential mechanisms. J. Nutr. 138:1746S-1751S.

Lampinen, B., Adaskaveg, J., Browne, G., Connell, J., Duncan, R. Michailides, T. J., and Metcalf, S. 2009. Lower limb dieback in almond Pages 178-185 in: Proceedings of Almond Board. Almond Board of California, Modesto, CA.

Latinović, J., Mazzaglia, A., Latinović, N., Ivanović, M., and Gleason, M. L. 2013 Resistance of olive cultivars to Botryosphaeria dothidea, causal agent of olive fruit rot in Montenegro. Crop Prot. 48:35-40.

Lazzizera, C., Frisullo, S., Alves, A., Lopes, J., and Phillips, A. J. L. 2008b. Phylogeny and morphology of Diplodia species on olives in southern Italy and description of Diplodia olivarum sp. nov. Fungal Divers. 31: 63-71.

Lazzizera, C., Frisullo, S., Alves, A., and Phillips, A. J. L. 2008a. Morphology, phylogeny and pathogenicity of Botryosphaeria and Neofusicoccum species associated with drupe rot of olives in southern Italy. Plant Pathol. 57: 948-956.

Lung, T., Lavalle, C., Hiederer, R., Dosio, A., and Bouwer, L. M. 2013. A multi-hazard regional level impact assessment for Europe combining indicators of climatic and non-climatic change. Glob. Environ. Change 23:522-536

Ma, Z., Morgan, D. P., and Michailides, T. J. 2001. Effects of water stress on Botryosphaeria blight of pistachio caused by Botryosphaeria dothidea. Plant Dis. 85:745-749.

Mahaffee, W. F., and Stoll, R. 2016. The ebb and flow of airborne pathogens: monitoring and use in disease management decisions. Phytopathology 106: 420-431.

Margier, R. 2014. Cécidomyie de l'olive et ses dégâts: la Dalmaticose. Nouvel Olivier 97:18-23.

Marsberg, A., Kemler, M., Jami, F., Nagel, J. H., Postma-Smidt, A., Naidoo, S., Wingfield, M. J., Crous, P. W., Spatafora, J. W., Hesse, C. N., Robbertse, B., and Slippers, B. 2017. Botryosphaeria dothidea: a latent pathogen of global importance to woody plant health. Mol. Plant Pathol. $18: 477-488$

Martos, S. 2008. El decaimento de la vid. Enfermedades de la madera relacionadas con hongos de la familia Botryosphaeriaceae. Ph.D. Thesis, Autonomic University of Barcelona, Barcelona, Spain.

McDonald, B. A., and Linde, C. 2002. Pathogen population genetics, evolutionary potential and durable resistance. Annu. Rev. Phytopathol. 40:349-379. 


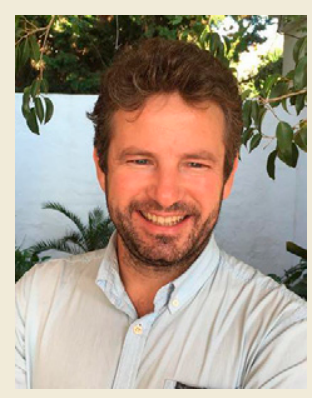

\section{Juan Moral}

Juan Moral, closely linked to olive and almond crops since his youth, is a researcher of plant pathology at the University of Cordoba, Spain. He received a Ph.D. degree in plant pathology in 2009 from the University of Cordoba. As a postdoctoral researcher, he has worked at UC-Davis (California), the Institute for Sustainable Agriculture (Spain), the Volcani Center (Israel), and the Catholic University of the Sacred Heart (Italy). He has conducted his research on etiology, applied epidemiology, breeding for resistance, and control of plant pathogens, with an emphasis on fungi and parasitic plants affecting woody crops and legumes under Mediterranean conditions. His teaching activity has covered courses of integrated pest management of olive and grapevine diseases, plant disease resistance, and experimental design in agronomy. He is a member of the American and Spanish Phytopathological Societies. He has been the principal investigator of two Marie Skłodowska-Curie projects (Talent Hub Cofund and IOF) on biological control of aflatoxins affecting nut crops that have been conducted between UC-Davis (at Kearney Agricultural Research and Extension) and the University of Cordoba.

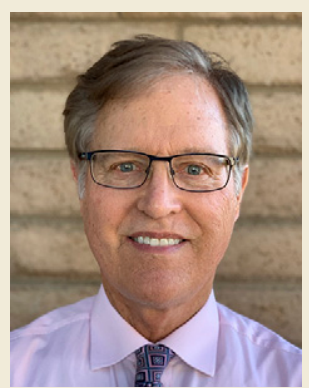

\section{David Morgan}

Mr. David Morgan received his B.S. degree in soil science at California State University, San Luis Obispo, and his M.S. degree in plant pathology from the University of California, Davis. He worked at the Kearney Agricultural Research and Extension Center from 1979 until he retired in 2017. During his time at Kearney, he worked on breeding pistachios for resistance to Verticillium wilt and then on the ecology, epidemiology, and control of diseases of fruit and nut trees in the San Joaquin and Sacramento valleys. His work was increasingly devoted to working on diseases of nut crops caused by Botryosphaeriaceae fungi, until he retired from Kearney. He is now involved on plant disease diagnostics and determines populations of soilborne pathogens for Nematodes, Inc. in Selma, California.

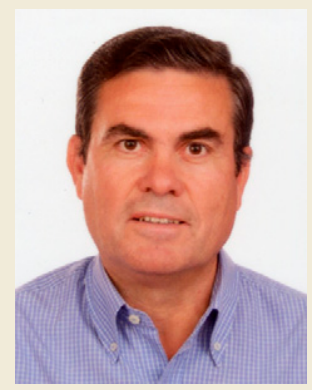

\section{Antonio Trapero}

Antonio Trapero-Casas is a professor of plant pathology in the Higher Technical School of Agricultural and Forestry Engineering at the University of Cordoba, Spain. His teaching activity conducted over 40 years has covered courses of general plant pathology, forest pathology, identification of plant pathogenic fungi, epidemiology, statistical methods applied to agronomy, and integrated management of plant diseases. His research, eminently applied, focuses on epidemiology, pathogen population biology, host resistance, and integrated management of plant diseases including the use of agronomic, biological, and chemical methods. This research has covered the main diseases of different crops, including olive, nuts, chickpea, legumes, grapevine, and forest trees. This work is developed in close collaboration with the agri-food sector and has received several national and international awards. He has served as director of the Department of Agronomy at the University of Córdoba, member of the board of directors of the Spanish Society of Phytopathology, and member of the Agri-Food Committee of the Andalusian Research Program. He was visiting scientist in the Department of Plant Pathology, Washington State University, Pullman; the International Center for Agricultural Research in the Dry Areas, Aleppo, Syria; and the Plant Cell and Molecular Biology Laboratory, King's College, London.

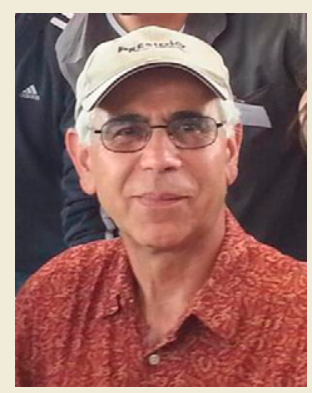

\section{Themis Michailides}

Themis J. Michailides is currently a plant pathologist located at the Kearney Agricultural Research and Extension Center in Parlier, CA. Michailides is a leading authority in fungal fruit tree and nut crop pathology and is nationally and internationally recognized for his innovative ecological, epidemiological, and disease management studies of devastating diseases of fruit crops such as brown rot in stone fruit (population dynamics, epidemiology, fungicide resistance, preharvest and postharvest detection, and disease management), Botrytis gray mold of kiwifruit and pistachio, fig endosepsis and smut of figs, Botryosphaeria of pistachio, almond, and walnut, and aflatoxin and ochratoxin contamination of nut crops (pistachio and almond) and figs. A pioneering contribution of Michailides' research project was the discovery of resistance mechanisms of Alternaria alternata to strobilurin fungicides and the first in the world identification of the mutations that confer resistance to a carboxamide boscalid. He has been a pioneer in the detection of fungal latent infections (Monilinia spp., Botrytis cinerea, and Botryosphaeria fungi) and the development of practical techniques that are used now commercially by private laboratories to help California growers and growers worldwide to make decisions in disease management. The most recent pioneering accomplishment was the registration of the atoxigenic Aspergillus flavus strain AF36 in pistachio to reduce aflatoxin contamination, which is now widely used. Also in 2017, the same biological control agent was registered for use in almond and fig orchards.

Michailides, T. J. 1991. Pathogenicity, distribution, sources of inoculum, and infection courts of Botryosphaeria dothidea on pistachio. Phytopathology 81:566-573.
Michailides, T. J., Chen, S. F., Morgan, D., Felts, D., Nouri, M. T., Puckett, R., Luna, M., Hasey, J., Anderson, K., Coates, W., Fichtner, E., Buchner, R. and Bentley, W. 2013. Managing Botryosphaeria/Phomopsis cankers and 
anthracnose blight of walnut in California. Pages 188-197 in: Proceedings of Walnut Board. Walnut Board of California, Folsom, CA.

Michailides, T. J., Inderbitzin, P., Connell, J. H., Luo, Y. G., Morgan, D. P., and Puckett, R. D. 2018. Understanding band canker of almond caused by Botryosphaeriaceae fungi and attempts to control the disease in California. Acta Hortic. 1219:303-310.

Michailides, T. J., Morgan, D., Felts, D., Luo, Y., Hasey, J., Symmes, H., Coates, W., Buchner, R., Lightle, D., Fichtner, E., Grant, J., Rodriguez, D., and Cunningham, C. 2015. Epidemiology and management of Botryosphaeriaceae/Phomopsis canker and blight and anthracnose blight of walnut in California. Pages 349-376 in: Walnut Research Reports. California Walnut Board, Folsom, CA.

Michailides, T. J., and Morgan, D. P. 1992. Effects of temperature and wetness duration on infection of pistachio by Botryosphaeria dothidea and management of disease by reducing duration of irrigation. Phytopathology 82:1399-1406

Michailides, T. J., and Morgan, D. P. 1993. Spore release by Botryosphaeria dothidea in pistachio orchards and disease control by altering the trajectory angle of sprinklers. Phytopathology 83:145-152.

Michailides, T. J., and Morgan, D. P. 2004. Panicle and shoot blight of pistachio: A major threat to the California pistachio industry. APSnet Feature Story January.

Michailides, T. J., and Morgan, D. P. 2016. Association of Botryosphaeria panicle and shoot blight of pistachio with injuries of fruit caused by Hemiptera insects and birds. Plant Dis. 100:1405-1413.

Michailides, T. J., Morgan, D. P., Felts, D., Hasey, J., Puckett, R. D., Luo, Y., Nouri, M. T., Luna, M., Anderson, K., Buchener, R., Fichtner, E., and Coates, W. 2014. Managing Botryosphaeria/Phomopsis canker and blight and anthracnose blight of walnut in California. Pages 299-317 in: Walnut Research Reports. California Walnut Board, Folsom, CA.

Michailides, T. J., Morgan, D. P., Interbitzin, P., Lampinen, B., Reyes, H., Puckett, R., Windh, J., Connell, J., Duncan, D., Holtz, B., Adaskaveg, J., Edstrom, J., Krueger, B., Viveros, B., Verdegaal, P., Browne, G., McCoy, D., Puget, B., and Post, J. 2009. Etiology, Epidemiology, and Management of Lower Limb Dieback and Band Canker of Almonds. Pages 1-12 in: Production Research Report. California Pistachio Commission, Fresno, CA.

Mila, A. L., Driever, G. F., Morgan, D. P., and Michailides, T. J. 2005. Effects of latent infection, temperature, precipitation, and irrigation on panicle and shoot blight of pistachio in California. Phytopathology 95:926-932.

Mila, A. L., and Michailides, T. J. 2006. Use of Bayesian methods to improve prediction of panicle and shoot blight severity of pistachio in California. Phytopathology 96:1142-1147.

Mohammadi, H., Sarcheshmehpour, M., and Mafi, E. 2015. First record of Botryosphaeria dothidea associated with pistachio (Pistacia vera L.) panicle blight in Iran. J. Crop Prot. 4:39-42.

Moral, J., Agustí-Brisach, C., Pérez-Rodríguez, M., Xavíer, C., Raya-Ortega, M. C., Rhouma, A., and Trapero, A. 2017a. Identification of fungal species associated with branch dieback of olive and resistance of table cultivars to Neofusicoccum mediterraneum and Botryosphaeria dothidea. Plant Dis. 101: 306-316.

Moral, J., Ahimera, N., Felts, D. G., Morgan, D. P., and Michailides, T. J. 2017b. Effects of wound size, amount of sap, and number of blighted nuts on infection of pistachio organs by Neofusicoccum mediterraneum. Plant Dis. 101: 2027-2033.

Moral, J., Eldesouki-Arafat, I., Lopez-Escudero, F., Vargas-Osuna, E., Trapero, A., and Aldebis, H. 2016. Olive escudete, caused by Botryosphaeria dothidea, as result of the interaction fly-mosquito-fungus. Phytopathology 106:S135.

Moral, J., Jurado-Bello, J., Sánchez, M. I., Oliveira, R., and Trapero, A. 2012. Effect of temperature, wetness duration, and planting density on olive anthracnose caused by Colletotrichum spp. Phytopathology 102:974-981.

Moral, J., Lovera, M., Benitez, M. J., Arquero, O., and Trapero, A. 2007. First report of Botryosphaeria obtusa causing fruit rot of quince (Cydonia oblonga) in Spain. Plant Pathol. 56:351.

Moral, J., Luque, F., and Trapero, A. 2008. First report of Diplodia seriata, the anamorph of "Botryosphaeria" obtusa, causing fruit rot of olive in Spain. Plant Dis. 92:311

Moral, J., Morgan, D., and Michailides, T. J. 2019. Management of Botryosphaeria canker and blight diseases of temperate zone nut crops. Crop Prot. (accepted).

Moral, J., Muñoz-Díez, C., González, N., Trapero, A., and Michailides, T. J. 2010. Characterization and pathogenicity of Botryosphaeriaceae species collected from olive and other hosts in Spain and California. Phytopathology 100: 1340-1351.

Moral, J., Pérez-Rodríguez, M., Michailides, T. J., and Trapero, A. 2015. First report of the teleomorph of Neofusicoccum mediterraneum, a pathogen of olive. Phytopathology 105:S97.

Morgan, D. P., Driever, G. F., Felts, D., Krueger, W. H., and Michailides, T. J. 2009. Evaluation of two disease-warning systems for Botryosphaeria panicle and shoot blight of California pistachio and efficient control based on earlyseason sprays. Plant Dis. 93:1175-1181.

Ntahimpera, N., Driever, G. F., Felts, D. G., Morgan, D. P., and Michailides, T. J. 2002. Dynamics and pattern of latent infection caused by Botryosphaeria dothidea on pistachio buds. Plant Dis. 86:282-287.
Olmo, D. 2015. Etiología y control de las enfermedades fúngicas de la madera de almendro en la isla de Mallorca. Ph.D. Thesis. University of Valencia, Valencia Olmo, D., Armengol, J., León, M., and Gramaje, D. 2016. Characterization and pathogenicity of Botryosphaeriaceae species isolated from almond trees on the island of Mallorca (Spain). Plant Dis. 100:2483-2491.

Phillips, A. J. L., Alves, A., Abdollahzadeh, J., Slippers, B., Wingfield, M. J., Groenewald, J. Z., and Crous, P. W. 2013. The Botryosphaeriaceae: genera and species known from culture. Stud. Mycol. 76:51-167.

Phillips, A. J. L., Rumbos, I. C., Alves, A., and Correia, A. 2005. Morphology and phylogeny of Botryosphaeria dothidea causing fruit rot of olives. Mycopathol. 159:433-439.

Piškur, B., Pavlic, D., Slippers, B., Ogris, N., Maresi, G., Wingfield, M. J., and Jurc, D. 2011. Diversity and pathogenicity of Botryosphaeriaceae on declining Ostrya carpinifolia in Slovenia and Italy following extreme weather conditions. Eur. J. For. Res. 130:235-249.

Ponti, L., Gutierrez, A. P., Ruti, P. M., and Dell'Aquila, A. 2014. Fine-scale ecological and economic assessment of climate change on olive in the Mediterranean Basin reveals winners and losers. PNAS 111:55985603.

Rice, R. E., Phillips, P. A., Stewart-Leslie, J., and Sibbett, G. S. 2006. Olive fruit fly populations measured in Central and Southern California. Calif. Agric. 57: $122-127$.

Rice, R. E., Uyemoto, J. K., Ogawa, J. M., and Pemberton, W. M. 1985. New findings on pistachio problems. Calif. Agric. 39:15-18

Romero, M. A., Sánchez-Hernández, M. E., and Trapero, A. 2005. First report of Botryosphaeria ribis as a branch dieback pathogen of olive trees in Spain. Plant Dis. 89:208.

Rumbos, I. C. 1987. Twig and branch dieback of walnut trees induced by Botryosphaeria ribis. Plant Pathol. 36:602-605.

Sammonds, J., Jaspers, M. V., and Jones, E. E. 2016. Pre-infection processes of Botryosphaeriaceae spp.: adhesion of conidia to different substrata. Plan Pathol. 65:1142-1152.

Sánchez-Hernández, M. E., Dávila, A. R., De Algaba, A. P., Blanco-López, M. A. and Trapero, A. 1998. Occurrence and etiology of death of young olive trees in southern Spain. Eur. J. Plant Pathol. 104:347-357.

Sergeeva, V., Alves, A., and Phillips, A. J. L. 2009. Neofusicoccum luteum associated with leaf necrosis and fruit rot of olives in New South Wales, Australia. Phytopathol. Mediterr. 48:294-298.

Sergeeva, V., Tesoriero, L., Spooner-Hart, R., and Nair, N. 2005. First report of Macrophomina phaseolina on olives (Olea europaea) in Australia. Austral. Plant Pathol. 34:273-274.

Slippers, B., Boissin, E., Phillips, A. J. L., Groenewald, J. Z., Lombard, L. Wingfield, M. J., Postma, A., Burgess, T., and Crous, P. W. 2013. Phylogenetic lineages in the Botryosphaeriales: a systematic and evolutionary framework. Stud. Mycol. 76:31-49.

Slippers, B., Smit, W. A., Crous, P. W., Coutinho, T. A., Wingfield, B. D., and Wingfield, M. J. 2007. Taxonomy, phylogeny and identification of Botryosphaeriaceae associated with pome and stone fruit trees in South Africa and other regions of the world. Plant Pathol. 56:128-139.

Slippers, B., and Wingfield, M. J. 2007. Botryosphaeriaceae as endophytes and latent pathogens of woody plants: diversity, ecology and impact. Fungal Biol. Rev. 21:90-106.

Smith, B., and Hendrix, F. F. 1984. Primary infection of apple buds by Botryosphaeria obtusa. Plant Dis. 68:707-709.

Smith, D. R., Michailides, T. J., and Stanosz, G. R. 2001. Differentiation of a Fusicoccum sp. causing panicle and shoot blight on California pistachio trees from Botryosphaeria dothidea. Plant Dis. 85:1235-1240.

Stanosz, G. R., Blodgett, J. T., Smith, D. R., and Kruger, E. L. 2001. Water stress and Sphaeropsis sapinea as a latent pathogen of red pine seedlings. New Phytol. 149:531-538.

Swart, W. J., and Botes, W. M. 1995. First report of stem canker caused by Botryosphaeria obtusa on pistachio. Plant Dis. 79:1036-1038.

Taylor, J. W., Jacobson, D. J., Kroken, S., Kasuga, T., Geiser, D. M., Hibbett, D. S., and Fisher, M. C. 2000. Phylogenetic species recognition and species concepts in fungi. Fungal Genet. Biol. 31:21-32.

Teviotdale, B. L., Michailides, T. J., and Pscheidt, J. W., eds. 2002. Compendium of nut crop diseases in temperate zones. The American Phytopathological Society, St. Paul, MN.

Theissen, F., and Sydow, H. 1918. Vorentwürfe zu den Pseudosphaeriales. Ann. Mycologici 16:1-34.

Thümen, F. 1883. Die Pilze des Oelbaumes. Boll. Soc. Adriat. Sci. Trieste 8: 215-244.

Trapero, A., Roca, L. F., Trapero, C., López-Escudero, F. J., and Moral, J. 2011. Diseases and their control. Pages 89-135 in: Culture and Knowledge Inspired by Olive Oil. J. Humanes, J. Villar, M. Fialho, and P. Higueras, eds. GEA Westfalia Separator Iberica SA, Ubeda-Jaén, Spain.

Úrbez-Torres, J. R., Bruez, E., Hurtado, J., and Gubler, W. D. 2010. Effect of temperature on conidial germination of Botryosphaeriaceae species infecting grapevines. Plant Dis. 94:1476-1484.

Úrbez-Torres, J. R., Peduto, F., Vossen, P. M., Krueger, W. H., and Gubler, W. D. 2013. Olive twig and branch dieback: etiology, incidence, and distribution in California. Plant Dis. 97:231-244.

Von Arx, J. A., and Müller, E. 1954. Die Gattungen der amerosporen Pyrenomyceten. Beitr Kryptogamenfl Schweiz 11:1-434. 
Wunderlich, N., Costa, S. S., Tpoi, R. P., and Ash, G. J. 2012. First report of Botryosphaeria dothidea causing shoot blight and cankers of pistachio in Australia. Aus. Plant Dis. Not. 7:47-49.

Yu, Z., Tang, G., Peng, S., Chen, H., and Zhai, M. 2015. Neofusicoccum parvum causing canker of seedlings of Juglans regia in China. J. For. Res. 26:1019-1024.

Zachos, D. G., and Tzavella-Klonari, K. 1979. Recherches sur l'identité et la position systématique du champignon qui provoque la maladie de olives attribuée au champignon Macrophoma o Sphaeropsis dalmatica. Ann. Inst. Phytopathol. Benaki 12:9-71.

Zachos, D. G., Tzavella-Klonari, K., and Roubos, J. C. 1974. Disease of pistachio tree (Pistacia vera L.) caused by the fungus Camarosporium pistaciae n. $\mathrm{sp}$. Ann. Inst. Phytopathol. Benaki 11:53-58.

Zadoks, J. C., and Schein, R. D. 1979. Epidemiology and plant disease management. Oxford University Press, New York. 